\title{
Próba porównania polskiego bezokolicznika i greckiego trybu zależnego
}

\section{The attempt of comparison of Polish infinitive verbal category and Greek conjunctive mood}

\author{
Kamil Trąba \\ INSTYTUT JĘZYKOZNAWSTWA, UNIWERSYTET IM. ADAMA MICKIEWICZA \\ AL. NIEPODLEGŁOŚCI 4, 61-874 POZNAŃ \\ prooffek@gmail.com
}

\begin{abstract}
The objective of the paper is an attempt of comparison of Polish infinitive verbal category and Greek conjunctive mood. The main attention was paid to differences and similarities both of their morphology and functions.

The present paper can be divided into three main parts. Firstly, the question of the aspect of Polish infinitive and of conjunctive in Greek is raised. Secondly, the morphology of Polish infinitive and Greek conjunctive systems are presented and compared, showing how different these languages are at this point. Part three concerns similarities and differences in usage of the Polish infinitive and the Greek conjunctive construction according to the aspectuality. The research showed that although most of the functions of the aspects are similar, their usage can differ according to speaker's intentions. Moreover, the main difference between the languages in question is based on a different interpretation of the closed-time expressions.
\end{abstract}

\section{Cel, przedmiot, metoda}

Celem niniejszego artykułu jest dyskusja na temat podobieństw i różnic w sposobach realizacji informacji gramatycznej, niesionej przez bezokolicznik, w języku polskim i nowogreckim. Przedmiot badań stanowią konstrukcje języka polskiego, w których używana jest niefinitywna forma czasownika - bezokolicznik - oraz odpowiadające im greckie konstrukcje trybu zależnego (koniunktywu, łac. coniunctivus, ang. conjuntive,). Zostaną one ze sobą porównane, ze szczególnym uwzględnieniem wartości aspektualnych przyjmowanych przez obie te kategorie. Głównym założeniem pracy jest możliwość stwierdzenia ekwiwalencji funkcjonalnej (Fisiak 1990) pomiędzy dwiema różnymi kategoriami gramatycznymi, mianowicie między polskim bezokolicznikiem a greckim trybem zależnym. Stwierdzenie takiej ekwiwalencji umożliwia prowadzenie dalszych badań porównawczych nad systemami aspektualnymi obu języków.

Ponieważ pole funkcjonalne greckiego trybu zależnego jest dużo szersze od mocno wyspecjalizowanej funkcji bezokolicznika w języku polskim, w czasie badań, polskim zdaniom z infinitywem przypisano konstrukcje ekwiwalentne w języku nowogreckim. Umożliwiło to 
ograniczenie się tylko do tych sytuacji językowych, w których równorzędność obu kategorii została stwierdzona.

Badania przeprowadzono na podstawie korpusu zdań greckich wybranych z prasy oraz

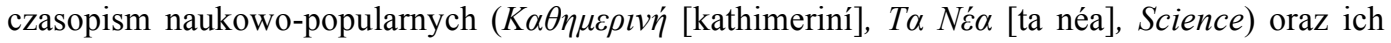
polskich ekwiwalentów semantyczno-pragmatycznych nastawionych szczególnie na znalezienie bezokolicznikowych ekwiwalentów strukturalnych (bezokoliczników i konstrukcji koniunktywnych).

\section{Stan badań}

\subsection{Aspekt}

Aspekt stanowi jedną z kategorii często pomijanych przez językoznawców, a nieraz nawet $\mathrm{i}$ niewyodrębnianą z kategorii czasu, z którym, bądź co bądź, jest obligatoryjnie związany. (Comrie $1976,5)$. Jest to spowodowane z jednej strony przez gramatykę tradycyjną wywodzącą się z myśli filozoficznych starożytnej Grecji a później Rzymu, kiedy to powstawały pierwsze gramatyki i traktaty o tematyce językowej (Milewski 1972, 31-2), z drugiej zaś synkretycznym charakterem form fleksyjnych w wielu językach, takich jak np. łacina, czy starogrecki, nie wspominając już o niewerbalnych sposobach wyrażania aspektu (jak np. w języku fińskim aspekt wyrażany jest przez formę fleksyjną dopełnienia bliższego). Co za tym idzie, trudno wyodrębnić niezależne markery czasu i aspektu. Ponadto, nawet w językach słowiańskich, w których kładzie się największy nacisk na dystynktywność aspektualną w systemie werbalnym (Comrie 1976, 1), kwestia czy sama kategoria aspektu jest w języku polskim kategorią fleksyjną, czy też słowotwórczą, pozostaje kontrowersyjna i jak dotąd nierozstrzygnięta (Laskowski 1998).

Aspekt, w przeciwieństwie do czasu, jest niedeiktyczną kategorią gramatyczną, która opisuje wydarzenia w sposób subiektywny, oparty na perspektywie osoby mówiącej (Comrie 1976, Laskowski 1998).

Najprostszą a zarazem najczytelniejszą formą przedstawienia podziału aspektu, jego rodzajów oraz relacji, w jakich stoją jego poszczególne elementy względem siebie, jest forma schematu:

Jak widać na poniższym schemacie, wyróżniamy aspekt dokonany (perfektyw, ang. perfective perfcv.) i niedokonany (imperfektyw, ang. imperfective - imperfcv.), w ramach którego można wyróżnić podtypy takie jak zwyczajowy (habitualny, ang. habitual) i ciągły. Zostaną one dokładniej omówione w dalszej części pracy. Warto jednak w tym miejscu rozróżnić między sobą dwie, diametralnie różne, a niekiedy mylone nawet przez językoznawców (Comrie 1976, 12), kategorie gramatyczne, mianowicie perfektyw i perfectum. Pierwsza z nich jest kategorią aspektu dokonanego, a druga jest czasem przeszłym o rezultacie teraźniejszym (uprzednioteraźniejszym).

Schemat 1. Podział aspektu .

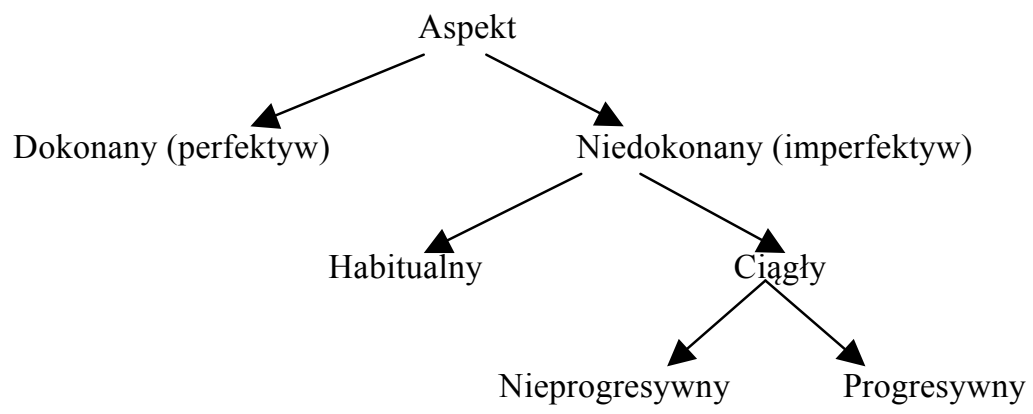

Aspekt może być definiowany na kilka różnych sposobów, zgodnie $\mathrm{z}$ przytoczonymi $\mathrm{w}$ niniejszym artykule opracowaniami. W pracy zostanie jednak zaprezentowanych tylko kilka $\mathrm{z}$ nich, a mianowicie te, które w sposób jak najbardziej czytelny charakteryzują sam aspekt, jak również pokazują różnice w funkcjach jego podtypów. 


\section{Investigationes Linguisticae, vol. XXVI}

\subsubsection{Aspekt dokonany}

Aspekt dokonany ma charakter punktowy, reprezentuje czynności skończone, niepodzielne na elementy i fazy składowe. Mówiąc inaczej, nie można wyodrębnić poszczególnych faz zachodzenia danej czynności, zjawiska czy akcji. Jest to niejako sposób ,patrzenia” na sytuację z zewnątrz, bez zagłębiania się w jej wewnętrzną strukturę. Często obrazuje się to stwierdzeniem, że czynność dokonana jest ograniczona bądź zredukowana dojednego punktu stanowiącego niepodzielną całość (Comrie 1976). Ponadto ma on charakter komplementarny (kompletywny), czyli zamknięty, retrospektywny. Narrator „patrzy” na czynność z jakiegoś późniejszego punktu/odcinka w czasie w stosunku do opisywanej czynności. Dana czynność jest traktowana jako pewien fakt zamknięty (dokonany), którego przebieg oraz fazy rozwoju w czasie są nieistotne (Kuryłowicz 1987). Kuryłowicza podkreśla niepodzielność, „punktowość” aspektu dokonanego. Nie da się wyróżnić poszczególnych jednorodnych faz czy elementów, które, nawet jeśli istnieją, są całkowicie irrelewantne. Można jednak wyróżnić przynajmniej dwie fazy niejednorodne: stan rzeczy przed czynnością wyrażaną przez czasownik dokonany i stan będący efektem, wywołany, stworzony przez daną czynność. Istotą aspektu jest ,zmiana stanu, w wyniku której powstaje nowa sytuacja (nowy stan)" (Laskowski 1998, 157). Można to zilustrować za pomocą następujących

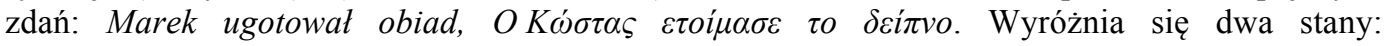
wcześniejszy, kiedy jeszcze obiadu nie było, i późniejszy (po ugotowaniu obiadu przez Marka/Kostasa), kiedy był on już gotowy (Laskowski 1998).

\subsubsection{Aspekt niedokonany}

Aspekt niedokonany, w przeciwieństwie do dokonanego, odwołuje się do wewnętrznej struktury czynności nie wyrażając ani jej początku ani końca lecz trwanie w czasie. „Patrzy” na nią z wewnątrz (Comrie 1976). Kuryłowicz (1987) przypisuje imperfektywowi cechę kursywności (Comrie nazywa ją continuousness - ciągłością), co oznacza, że czynność, stan lub proces jest przedstawiany w trakcie dziania się, trwania (w czasie wyznaczonym przez kategorię czasu gramatycznego). Aspekt niedokonany można podzielić na elementy składowe, jednorodne fazy, wydzielenie początku, środka oraz końca czynności (Laskowski 1998). Osoba mówiąca w wypowiedzi może swobodnie przemieszczać się w obrębie czynności niedokonanej i skierować się wstecz - ku jej początkowi lub do przodu - ku końcowi (Comrie 1976).

Ponadto, w obrębie aspektu niedokonanego wyodrębnia się funkcję iteratywną (powtarzalną) oraz habitualną (zwyczajową). Obie związane są bezpośrednio z wielokrotnością, powtarzalnością czynności ${ }^{1}$. Przedstawiają one opis serii powtarzających się zdarzeń, które nie koniecznie dzieją się w chwili mówienia (Laskowski 1998). Habitualność podkreśla zwyczajowość, regularność występowania danej czynności i jednocześnie, gdy odnosi się do przeszłości, że nie ma ona już miejsca w teraźniejszości (Comrie 1976).

Oprócz tego, imperfektyw może być użyty do wyrażenia zamkniętego faktu (w znaczeniu bliskim perfektywowi). Laskowski $(1998,161)$ przedstawia następujące przykłady: $C z y$ widziałeś/ogladałeś ten film? czytałem ostatnio najnowszy tomik Krynickiego, Marek siedział u nich godzinę. Dodaje jednocześnie, że czasowniki te mogą być stosowane wymiennie z odpowiadającymi im formami dokonanymi bez zmiany znaczenia wypowiedzi. W języku nowogreckim, odpowiednikiem funkcjonalnych dla powyższych zdań stanowi konstrukcja czasu

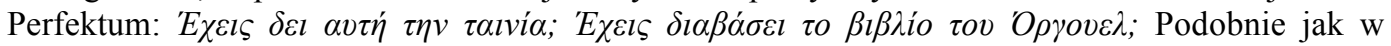
języku polskim, w zdaniach tych Perfektum może zostać zastąpiony czasem przeszłym dokonanym bez zmiany znaczenia.

Kończąc, aspekt dokonany przedstawia fakt zamknięty (komplementarność) spoglądając na niego z późniejszego puntu w czasie (retrospekcja), redukując jednocześnie go do jednego, jednolitego i niepodzielnego punktu (punktowość) oraz wytwarzając nowy stan. Z kolei czasowniki niedokonane przedstawiają czynność od wewnątrz w czasie jej trwania (ciągłość/linearność), którą można podzielić na poszczególne fazy i obserwować jej rozwój w

\footnotetext{
${ }^{1}$ Ten sposób definiowania jest o tyle zwodniczy, że w przypadku zdefiniowanej ilości, bądź zaledwie parokrotności danego zdarzenia, używany jest aspekt dokonany. Np.: Marek ugotował obiad dwa/trzy razy (Comrie, 1976).
} 
czasie (progresywność). Oprócz tego przedstawiają czynności regularne (habitualność), mające miejsce wielokrotnie (iteratywność) bądź mające charakter uniwersalny (omnitemporalność).

\subsection{Bezokolicznik}

Bezokolicznik jest niefinitywną formą czasownika, czyli taką, jaka nie odmienia się przez osoby oraz liczby. W wielu językach stanowi podstawową formę czasownika. W językach takich jak np. j. angielski, infinitivus bazowy (ang. bare infinitive) jest formą nieoznaczoną morfologicznie - nie jest tworzony fleksyjnie poprzez dodanie odpowiedniego morfemu gramatycznego. Co za tym idzie, stanowi czysty temat werbalny. W innych językach, jak np. w języku polskim, niemieckim czy włoskim, bezokolicznik tworzony jest poprzez dodanie do tematu odpowiedniego markera (Crystal 2008) (w j. pol. jest to -ć lub - c, który jest w rzeczywistości morfemem zerowym dla czasowników atematycznych podklasy $5 \mathrm{~d}$ oraz czasowników rozszerzających temat podstawowy o -ną- $\mathrm{z}$ tematem zakończonym na -k, -g (Laskowski 1998), w j. niemieckim jest to -(e)n, w j. włoskim $-\mathrm{re}, \mathrm{w}$ j. hiszpańskim $-\mathrm{r}$ a fińskim $\left.-(\mathrm{t} / \mathrm{d} / \mathrm{S}) \mathrm{A}^{2}\right)$. Cechą charakterystyczną bezokolicznika jest to, że zazwyczaj nie odmienia się on ani przez osoby, ani przez czasy, tryby, liczby, przypadki, aspekty, choć $\mathrm{w}$ różnych językach może on przyjmować którąś z tych kategorii. Tak dla przykładu, w języku polskim inf. może przyjąć (fleksyjnie bądź słowotwórczo ${ }^{3}$ ) (Laskowski 1998) wartość aspektu dokonanego, bądź niedokonanego, jak np.: pisać : napisać, czytać : przeczytać, jeść : zjeść, wychować : wychowywać, wyciąć : wycinać.

Warto również wspomnieć o językach, które nie posiadają bezokolicznika, bądź jest to forma szczątkowa, ograniczona do ściśle utartych kontekstów językowych. Przykładem takiego języka może być język nowogrecki, którego „bezokolicznik” (verbum infinitum) zachował się tylko i wyłącznie w formach złożonych czasów perfektum (Plqmperf., Perf, i Fut. perf.) (Triandafillidis

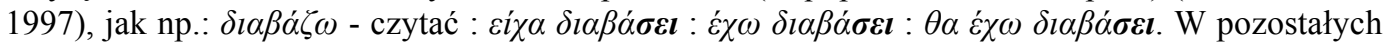
kontekstach, podobnie jak w językach południowosłowiańskich (np. bułgarski), forma bezokolicznika została zastąpiona formą złożoną trybu zależnego (Comrie 1976, Dalewska-Greń

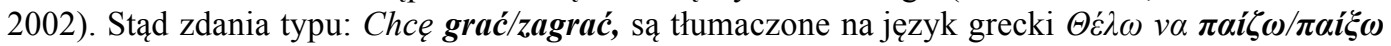
(dosłownie: chcę żebym grał/zagrał). Jest to cecha typowa dla języków ligi bałkańskiej (m. in. Joseph 1981, Milewski 1972).

\subsubsection{Funkcje bezokolicznika w języku polskim}

Ze składniowego punktu widzenia, bezokolicznik traktowany jest jako składnik zdania złożonego (Grochowski, Karolak, Topolińska 1984) lub jako składnik z pogranicza zdania pojedynczego i złożonego (Grzegorczykowa 2004), który najczęściej jest konotowany przez orzeczenie. Stanowi on formę akomodowaną w zdaniu, będącą podrzędnikiem orzeczenia (nadrzędnika), czyli formy finitywnej czasownika (Saloni, Świdziński 2007). Ponieważ infinitivus stanowi jeden ze sposobów nominalizacji zdania, może być w niektórych kontekstach stosowany wymiennie z rzeczownikami lub zdaniami podrzędnymi (Grzegorczykowa 2004, Saloni, Świdziński 2007, Grochowski, Karolak, Topolińska 1984). Zilustrować to można następującymi przykładami: Lubi spacerować : Lubi spacery, Postanowił się nie wtracać : postanowit, że nie będzie się wtrącal, wyszedt przestawić samochód : wyszedt, żeby przestawić samochód. Ponadto, bezokolicznik może pełnić (w sposób całkowicie regularny) funkcję okolicznika celu w zdaniach pojedynczych czasowników ruchu ukierunkowanego (Klemensiewicz 1968, Grzegorczykowa 2004). Przykładem takiego

\footnotetext{
2 Jest to tzw. Infinitivus I, który stanowi słownikową formę podstawową czasownika. S oznacza spółgłoski płynne (ang. semivowel) a A reprezentuje dźwięk a lub ä, których użycie uwarunkowane jest zasadami harmonii wokalicznej.

${ }^{3} \mathrm{~W}$ tej pracy zakładam, że formy aspektualne tworzone są w sposób fleksyjny, dzięki czemu praca będzie bardziej czytelna i przejrzysta. Więcej na temat dyskusji, czy system czasownikowy języka polskiego tworzy formy fleksyjnie czy słowotwórczo można znaleźć w Gramatyka Współczesnego Języka Polskiego: Morfologia, R. Grzegorczykowa, R. Laskowski, H. Wróbel, Wydawnictwo Naukowe PWN 1998, w rozdziale: Zagadnienia ogólne morfologii, podrozdział 5.2.2. Aspekt.
} 


\section{Investigationes Linguisticae, vol. XXVI}

zdania jest np. podana wyżej wypowiedź: wyszedt przestawić samochód (wyszedt, żeby przestawić samochód), lub idę coś zjeść (idę, żeby coś zjeść).

Użycie bezokolicznika nie jest jednak w pełni dowolne i swobodne. Najważniejszym czynnikiem, który musi zostać spełniony, aby w zdaniu mogła pojawić się forma niefinitywna, jest zgodność podmiotu orzeczenia głównego i bezokolicznika (Grzegorczykowa 2004, Grochowski, Karolak, Topolińska 1984). Dlatego np. poprawne jest zdanie: Marek chce wyjechać za granice, w którym Marek jest zarówno podmiotem dla chce jak i dla wyjechać. Konstrukcja ta jednak nie jest możliwa w przypadku zdania: Marek chce, by Marysia wyjechała za granice (Marek chce Marysia wyjechaé).

Ze względu na łączliwość leksemów werbalnych z bezokolicznikiem, można je podzielić na trzy kategorie (Saloni, Świdziński, 2007, 135):

1) $\mathrm{V}(\Theta \mathrm{Inf})$ - czasowniki, które nie dopuszczają bezokolicznika np.: widzieć, burzyć, pisać, itp.,

2) $\mathrm{V}\left(\operatorname{Inf}^{\mathrm{I}}\right)$ - czasowniki dopuszczające tylko i wyłącznie formę bezokolicznikową czasowników właściwych (posiadających podmiot) np.: trzeba, zachcieć się, wolno, itp.,

3) $\mathrm{V}\left(\operatorname{Inf}^{\mathrm{II}}\right)$ - czasowniki łączące się $\mathrm{z}$ formą bezokolicznikową czasowników zarówno właściwych jak i niewłaściwych np.: zaczynać, przestać, móc, powinien, itp.

$\mathrm{Na}$ zakończenie warto wymienić grupy zdaniowe z podrzędnikiem czasownikowym $\mathrm{w}$ formie infinitivu (Saloni, Świdziński, 2007):

- grupa czasownika dzieli się na dwa podtypy: konotującą inf. - tzw. czasowniki V(inf $\left.{ }^{\mathrm{I}}\right)$ i V(inf ${ }^{\mathrm{II}}$ ) jak np.: chcieć, umieć, lubić - oraz niekonotująca - V(Oinf) np.: pobiec (coś zrobić), iść (coś zrobić)

- $\quad$ grupa rzeczownikowa (bardzo nieliczna), np.: mieć ochotę, podjąć decyzję

- $\quad$ grupa przymiotnikowa dzieli się na dwie podgrupy: konotujące, jak np.: być chętnym, być gotowym, oraz niekonotowane jak np. w zdaniu: uczniowie idacy ${ }^{4}$ kupić chleb powinni uważać,

Pozostałe grupy, czyli liczebnikowa i przysłówkowa, nie są realizowane z podrzędnikiem czasownikowym ${ }^{5}$.

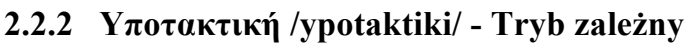

Jak zostało wspomniane wcześniej, język nowogrecki, który należy do ligi języków bałkańskich, utracił bądź, według niektórych opracowań, szczątkowo zachował (Triandafillidis, 1997), kategorię bezokolicznika (Jurewicz, 1992). Tak zwane $\alpha \pi \alpha \rho \varepsilon ́ \mu \varphi \alpha \tau o$ /aparemfato/, czyli infinitivus, jest obecnie konstrukcją archaiczną, szczątkową, która zachowała się jedynie w peryfrastycznych konstrukcjach czasowych z czasownikiem posiłkowym mieć o charakterze perfekcyjnym oraz

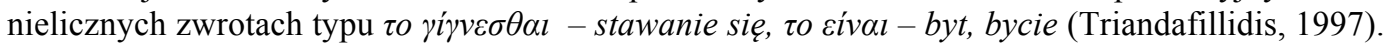
Pierwotny bezokolicznik został zastąpiona konstrukcją peryfrastyczną trybu zależnego

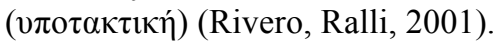

Tryb zależny w języku greckim posiada postacie: prostą, ciągła i perfektum ${ }^{6}$, które tworzone są $\mathrm{z}$ różnych tematów: $\mathrm{z}$ tematu aoristi (prostego, dokonanego, perfektywnego), tematu praesentis (ciągłego, niedokonanego, imperfektywnego) oraz przy pomocy konstrukcji Perfectum. Czasowniki w trybie zależnym odmieniają się przez osoby, liczby, strony oraz aspekt. W tabeli poniżej znajdują się formy trybu zależnego dla przykładowych czasowników w stronie czynnej i biernozwrotnej: $\gamma \rho \alpha \dot{\varphi} \varphi \omega^{7}$ - pisać, $\delta \alpha \beta \alpha ́ \zeta \omega$ - czytać, $\alpha \gamma \alpha \pi \omega ́$ - kochać, $\alpha \rho \gamma \omega ́$ - spóźniać się.

\footnotetext{
${ }^{4}$ Imiesłów przymiotnikowy czynny należą do grupy imiennej (odmiennej przez przypadki) przymiotnikowej (Saloni 2007, 102)

${ }^{5}$ Podział czasowników oraz grupy zdaniowe, które mogą posiadać, posiadają bądź nie dopuszczają podrzędnika czasownikowego w formie bezokolicznika, a także niektóre przykłady zostały wzięte ze Sktadnia Wspótczesnego Języka Polskiego Z. Saloniego i M. Świdzińskiego (2007) str.135, 277, 280, 283, 285, 287.

${ }^{6}$ Występującą bardzo rzadko, co zostało stwierdzone na podstawie własnych badań prowadzonych na potrzeby pracy.

${ }^{7} \mathrm{~W}$ języku greckim, który nie posiada bezokolicznika, jako formę podstawową, z której derywowane są pozostałe tematy czasownikowe, podaje się $1 \mathrm{os}$. sg. trybu oznajmującego czasu teraźniejszego strony czynnej (w przypadku verbum deponens strony medialno-pasywnej).
} 
Tabela 1. Tworzenie form trybu zależnego w języku nowogreckim na przykładowych czasownikach ${ }^{8}$

\begin{tabular}{|c|c|c|c|}
\hline \multirow[b]{2}{*}{ Wokabuła $^{9}$} & \multicolumn{3}{|l|}{ Tryb zależny } \\
\hline & $\begin{array}{l}\text { ciagly } \\
\text { (imperfective) }\end{array}$ & prosty (perfective) & perfekcyjny (perfecti) \\
\hline$\gamma \rho \alpha ́ \varphi \omega$ & $v \alpha \gamma \rho \alpha ́ \varphi \omega$ & $v \alpha \gamma \rho \alpha ́ \psi \omega$ & $v \alpha \dot{\varepsilon} \chi \omega) \gamma \rho \alpha ́ \psi \varepsilon \mathbf{\varepsilon}$ \\
\hline$\gamma \rho \alpha ́ \varphi о \mu \alpha \imath$ & $v \alpha \gamma \rho \alpha ́ \varphi о \mu \alpha \imath$ & $v \alpha \gamma \rho \alpha \varphi(\tau) \dot{\omega}$ & $\nu \alpha \varepsilon \dot{\varepsilon} \chi \omega \gamma \rho \alpha \varphi(\tau) \varepsilon i ́$ \\
\hline$\delta 1 \alpha \beta \alpha ́ \zeta \omega$ & $v \alpha \delta 1 \alpha \beta \alpha ́ \zeta \omega$ & $v \alpha \delta 1 \alpha \beta \alpha ́ \sigma \omega$ & 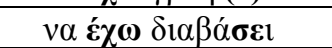 \\
\hline$\delta 1 \alpha \beta \alpha ́ \zeta о \mu \alpha \mathbf{~}$ & $v \alpha \delta 1 \alpha \beta \alpha ́ \zeta$ онаı & $v \alpha \delta i \alpha \beta \alpha \sigma \tau \omega$ & 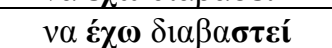 \\
\hline$\alpha \gamma \alpha \pi \dot{\omega}$ & $v \alpha \alpha \gamma \alpha \pi \dot{\omega}$ & 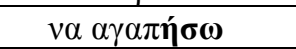 & $v \alpha \dot{\varepsilon} \chi \omega \alpha \gamma \alpha \pi \eta ́ \sigma \varepsilon \mathbf{\imath}$ \\
\hline$\alpha \gamma \alpha \pi \mathrm{l} \mathbf{\varepsilon} \mu \alpha \imath$ & $v \alpha \alpha \gamma \alpha \pi \imath \varepsilon \dot{\varepsilon} \mu \iota$ & $v \alpha \alpha \gamma \alpha \pi \eta \boldsymbol{\theta} \dot{\omega}$ & $v \alpha \dot{\varepsilon} \boldsymbol{\chi} \omega \alpha \gamma \alpha \pi \eta \dot{\theta} \boldsymbol{\varepsilon} \mathbf{i}$ \\
\hline$\alpha \rho \gamma \dot{\omega}$ & $v \alpha \alpha \rho \gamma \dot{\omega}$ & $v \alpha \alpha \rho \gamma \eta \dot{\sigma} \omega$ & 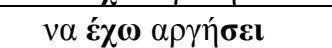 \\
\hline
\end{tabular}

Funkcje, które pełni tryb zależny w języku nowogreckim, są liczne i w bardzo dużym stopniu odbiegają od silnie wyspecjalizowanej i znacznie ograniczonej funkcji bezokolicznika w języku polskim. Dla przykładu, pełni on funkcję trybu rozkazującego, wyraża możliwości, życzenia, obawy, pragnienia i wprowadza zdania celowe (Kleris, Babiniotis, 2005, Holton, Mackridge, Philippaki-Warburton, 1998). Jednak przedmiotem niniejszej pracy nie są funkcje greckiego koniunktywu. Więcej informacji w tym zakresie można znaleźć w literaturze przedmiotu, takiej

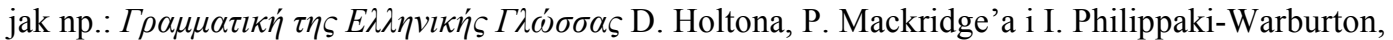

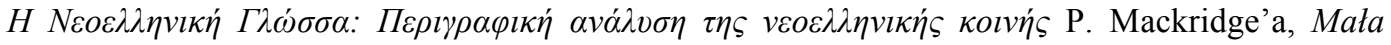
gramatyka nowogrecka M.A. Triandafillidisa.

\section{Tworzenie form bezokolicznika $w$ języku polskim i trybu zależnego $\mathrm{w}$ języku nowogreckim}

Jedną z najbardziej ewidentnych różnic między językiem polskim a nowogreckim jest istnienie $\mathrm{w}$ systemie językowym bezokolicznika. Współczesny język nowogrecki, na skutek widocznego uproszczenia się fleksji (Jurewicz, 1992), utracił bezokolicznik, a jego funkcję przejęła konstrukcja trybu zależnego $^{\mathbf{1 0}}$ (Comrie 1976, Jurewicz 1992, Joseph 1981 i inni). Mimo to, w opracowaniach gramatyk greckich nadal można się spotkać z terminem „,bezokolicznika”. Odnosi się on do konkretnej, niefinitywnej i całkowicie zależnej (od czasownika pomocniczego é $\chi \omega$ mieć) formy czasownikowej, używanej tylko i wyłącznie do tworzenia analitycznych form czasów Perfektum (Plusquamperfectum, Perfectum i Futurum Perfecti) (Triandafillidis, 1997). Tworzona jest ona $\mathrm{z}$ tematu aorystu (tematu dokonanego, zazwyczaj sygmatycznego), do którego dodawany jest morfem $-\varepsilon 1[-i]$.

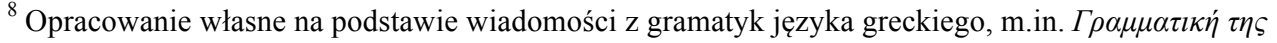

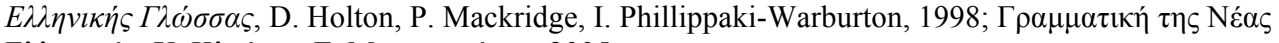

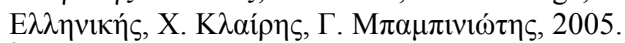

${ }^{9}$ Zachowując tradycję łacińską, słownikową formę czasownikową w języku nowogreckim (odpowiadającą polskiemu bezokolicznikowi) stanowi 1 os. sg. Ind. Preas. Act. (w przypadku verbum deponens Ind. Praes. Med.-Pass.)

${ }^{10}$ Ponieważ grecki tryb zależny może pełnić wiele różnych funkcji (zarówno w zdaniu podrzędnym jak i nadrzędnym), w dalszej części pracy terminy takie jak tryb zależny, koniunktiwus bądź coniunctivus (con.) będą odnosiły się tylko do tych konstrukcji, które w języku polskim można oddać przy pomocy bezokolicznika.
} 
Tabela 2. Tworzenie greckiego „bezokolicznika” w języku nowogreckim na przykładowych czasownikach ${ }^{11}$

\begin{tabular}{|c|c|c|c|c|}
\hline Praes. & Tem. Praes. & Tem. Aor. & Inf. & Perf. \\
\hline$\gamma \rho \alpha ́ \varphi \omega$ & $\gamma \rho \alpha \varphi-$ & $\gamma \rho \alpha \psi-$ & $\gamma \rho \alpha ́ \psi \varepsilon \iota$ & 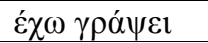 \\
\hline$\delta 1 \alpha \beta \alpha ́ \zeta \omega$ & $\delta 1 \alpha \beta \alpha \zeta$ & $\delta 1 \alpha \beta \alpha \sigma-$ & $\delta 1 \alpha \beta \alpha ́ \sigma \varepsilon \imath$ & $\varepsilon^{\prime} \chi \omega \delta 1 \alpha \beta \alpha ́ \sigma \varepsilon \imath$ \\
\hline$\alpha \gamma \alpha \pi \dot{\prime}$ & $\alpha \gamma \alpha \pi-$ & $\alpha \gamma \alpha \pi \eta \sigma-$ & $\alpha \gamma \alpha \pi \eta ́ \sigma \varepsilon \imath$ & $\dot{\varepsilon} \chi \omega \alpha \gamma \alpha \pi \eta ́ \sigma \varepsilon 1$ \\
\hline$\alpha \rho \gamma \omega ́$ & $\alpha \rho \gamma-$ & $\alpha \rho \gamma \eta \sigma-$ & $\alpha \rho \gamma \eta ́ \sigma \varepsilon 1$ & $\varepsilon \dot{\varepsilon} \chi \omega \alpha \rho \gamma \eta ́ \sigma \varepsilon 1$ \\
\hline 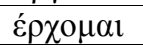 & $\varepsilon \rho \chi-$ & $\varepsilon \rho \theta-$ & $\varepsilon \rho \theta \varepsilon 1$ & $\varepsilon \chi \omega \dot{\varepsilon} \rho \theta \varepsilon 1$ \\
\hline
\end{tabular}

W języku polskim można odnaleźć analogiczną konstrukcję używaną do tworzenia czasu przyszłego poprzez czasownik posiłkowy „być”: czytam : będę czytać, piszę : będę pisać, kocham : będę kochać itd. Nie jest to jednak konstrukcja tak sztywna jak w języku greckim, ponieważ bezokolicznik występuje zamiennie z formą 3os. czasu przeszłego będę czytać/czytał(a), będziesz pisać/pisat(a), będa kochać/kochali(ty) itd. Kolejną różnicą, z punktu widzenia morfologii, jest to, że grecki „,bezokolicznik” tworzy się tylko i wyłącznie z tematu perfektywnego (aoristi). W języku polskim zaś, czasownik posiłkowy „być” łączy się z formą bezokolicznika niedokonanego.

Polski bezokolicznik oddawany jest w języku greckim poprzez tryb zależny. Oto dwa przykładowe zdania w języku greckim i polskim:

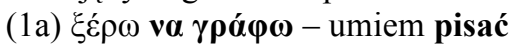

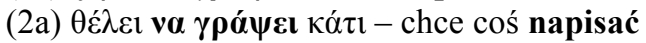

Jak widać na powyższych przykładach, w języku greckim forma zależna tworzona jest opisowo, za pomocą markera $v \alpha$,aby”, po którym występuje forma czasownikowa ciągła bądź prosta (Kleris, Babiniotis, 2005, Holton, Mackridge, Philippaki-Warburton, 1998, Triandafillidis, 1997, i inni). Natomiast język polski derywuje formę infinitywną w sposób fleksyjny, poprzez dodanie sufiksu -ć bądź -c (dawniej także -dz) (Laskowski 1998, Nagórko 2000).

Analizując głębiej powyższe zdania, można zauważyć, że grecki czasownik w trybie zależnym przyjmuje końcówki osobowe będące w związku zgody z podmiotem zdania, innymi słowy, odmienia się przez osoby. Zjawisko takie jednak nie występuje w przypadku języka polskiego, w którym bezokolicznik jest formą bezosobową:

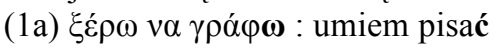

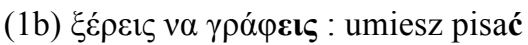

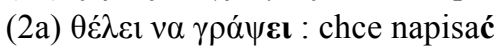

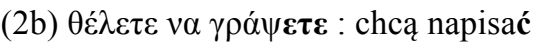

Następstwem tego jest fakt, że w języku nowogreckim podmiot zdania podrzędnego i podmiot zdania nadrzędnego nie musi być ten sam, przeciwnie do języka polskiego:

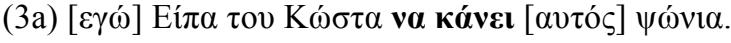

*[ja] Powiedziałem Kostasowi [on] zrobić zakupy.

[ja] Powiedziałem Kostasowi, aby [on] zrobił zakupy.

(3b) [on] Chce [on] kupić samochód.

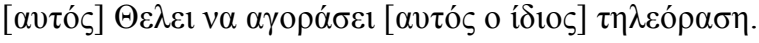

Tabela 3. Zgodność podmiotu zdania nadrzędnego i podrzędnego bezokolicznikowego w języku polskim i koniunktywnego w języku nowogreckim ${ }^{12}$

\begin{tabular}{|c|c|}
\hline język grecki & język polski \\
\hline $\mathrm{S}_{1}-\mathrm{O}-\mathrm{S}_{2}-\mathrm{I}$ & - \\
\hline $\mathrm{S}_{1}-\mathrm{O}_{1}-\left[\mathrm{S}_{1}\right]-\mathrm{I}$ & $\mathrm{S}_{1}-\mathrm{O}_{1}-\left[\mathrm{S}_{1}\right]-\mathrm{I}$ \\
\hline
\end{tabular}

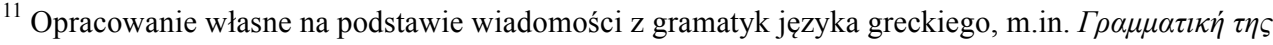

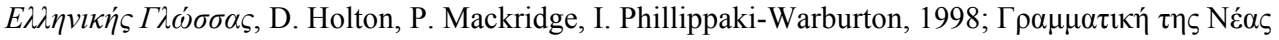

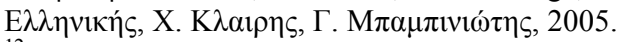

${ }^{12}$ Opracowanie własne. $\mathrm{S}$ - podmiot (ang. subject), $\mathrm{O}$ - orzeczenie (ang. object), I bezokolicznik/konstrukcja koniunktywna (ang. infinitive)
} 
Nim przejdziemy do dalszych porównań obu systemów językowych, należy wspomnieć, że w języku polskim wyróżnia się dwa aspekty: dokonany i niedokonany. Język grecki natomiast posiada jeszcze trzeci aspekt, tzw. perfect $^{13}$ :

$$
\begin{array}{lllll}
\text { pisać } & : & \text { napisać }: & : & - \\
v \alpha \gamma \rho \alpha ́ \varphi \omega & : & v \alpha \gamma \rho \alpha ́ \psi \omega & : & v \alpha \varepsilon \dot{\varepsilon} \chi \gamma \rho \alpha ́ \psi \varepsilon \varepsilon
\end{array}
$$

\subsection{Pary aspektowe}

Zarówno w języku polskim jak i greckim można mówić o czasownikowych formach niedokonanych (ciągłych, imperfektywnych) stojącej w opozycji do dokonanych (prostych, perfektywnych). Właściwość ta pozwala pogrupować czasowniki w pary aspektowe, w których jedna forma prezentuje formę niedokonaną a druga dokonaną. Właściwe połączenie bezokoliczników w pary aspektowe jest szczególnie ważne w przypadku języka polskiego, ponieważ derywacja tematów może przebiegać w dwie strony: derywacja pierwotna, gdy z tematu niedokonanego tworzony jest temat dokonany, oraz derywacja wtórna, gdy z tematu dokonanego urabiany jest temat niedokonany. Np.:

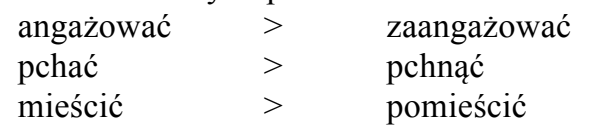

oraz

$\begin{array}{lll}\text { dać } & > & \text { dawać } \\ \text { doszukać się } & > & \text { doszukiwać się } \\ \text { podkreślić } & > & \text { podkreślać }\end{array}$

Problem, podczas łączenia form czasownikowych w pary aspektowe, stanowią tematy dokonane prefiksalne, których urabiania nie da się uporządkować za pomocą żadnych reguł. Wynika z tego, że poszczególny temat bazowy (niezłożony) może przyjąć pewien konkretny przedrostek bez zmiany znaczenia, jednak nie jest wiadome, co warunkuje, który to będzie z przedrostków (Laskowski 1998, Nagórko, 2010). Metodą, stosowaną do dzisiaj podczas łączenia tematów czasownikowych w pary aspektowe, jest zaproponowany przez Agrella na początku XX w. tzw. test formalny (Nagórko, 2010, 139). Polega on na tym, że jeśli od danego tematu złożonego przedrostkowego nie jest możliwe utworzenie wtórnej formy niedokonanej, to wówczas tworzą one (minimalną) parę aspektową. Jeżeli zaś istnieje dla danego tematu wtórna forma niedokonana, wówczas temat bazowy i złożony owej pary nie tworzą. Np.:

$$
\begin{array}{llll}
\text { ciąć } & \text { - pociąć }: & : & - \\
& \text { - przeciąć } & : & \text { przecinać } \\
& \text { - ściąć } & : & \text { ścinać } \\
& \text { - wyciąć }: & : & \text { wycinać }
\end{array}
$$

itd.

Słabym punktem testu Agrella jest łączenie w pary aspektowe niektórych czasowników stanu, takich jak np.: leżeć : poleżeć. $\mathrm{Z}$ tego też powodu, podczas łączenia czasowników w pary

\begin{tabular}{|c|c|c|c|c|}
\hline$v \alpha \varphi \tau \alpha ́ v \omega$ & $>$ & $v \alpha \varphi \tau \alpha \dot{\sigma} \sigma \omega$ & : & - \\
\hline$v \alpha \gamma \rho \alpha ́ \varphi \omega$ & $>$ & $v \alpha \gamma \rho \alpha ́ \psi \omega$ & : & $v \alpha \gamma \rho \alpha \varphi(\tau) \omega$ \\
\hline$v \alpha \zeta \eta \tau \dot{\omega}>$ & $>$ & $v \alpha \zeta \eta \tau \eta ́ \sigma \omega$ & : & $v \alpha \zeta \eta \tau \eta \theta \dot{\omega}$ \\
\hline$\alpha \rho v o v ́ \mu \alpha t$ & $>$ & - & : & $v \alpha \alpha \rho v \eta \theta \dot{\omega}$ \\
\hline
\end{tabular}
aspektowe należy zwrócić uwagę także na ich funkcje w różnych kontekstach.

$\mathrm{W}$ języku greckim derywacja tematyczna jest zawsze jednostronna, ponieważ temat dokonany urabiany jest tylko i wyłącznie z tematu niedokonanego (bądź rzadko - i nieregularnie - przez wymianę tematu), nigdy zaś na odwrót.

\subsection{Bezokolicznik niedokonany a tryb zależny ciągły}

\footnotetext{
${ }^{13}$ Należy zwrócić uwagę, by nie pomylić ze sobą Perfectu(m), rozumianego przez gramatyki tradycyjne jako czas, z perfectum, w znaczeniu aspektu czasu przeszłego, teraźniejszego bądź przyszłego (Comrie, 1976 : $10)$.
} 


\section{Investigationes Linguisticae, vol. XXVI}

Język polski jest językiem bogatszym derywacyjnie od greckiego, co widoczne jest podczas zestawienia ze sobą obu systemów. W języku polskim podstawę, od której urabiana jest forma bezokolicznika, może stanowić temat praes. (niedokonany), do którego dodawany jest sufiks infinitywny -ć, lub -c (Laskowski 1998, Nagórko 2000). W języku greckim podstawę również stanowi temat praes., do którego dodawane są teraźniejsze końcówki osobowe (stąd forma czasownika w ind. praes. jest identyczna $\mathrm{z}$ formą czasownika w trybie zależnym ciągłym) a przed którym stawiany jest marker $v \alpha$.

Tabela 4. Tworzenie bezokolicznika niedokonanego i ciągłego trybu zależnego z tematu praes ${ }^{14}$

\begin{tabular}{|c|c|c|c|}
\hline czas. w 1 os. sg. & czas. w 2 os. sg. & temat praes. & inf. / konstr. inf. \\
\hline kończę & kończysz & kończy- & kończyć \\
\hline gromadzę & gromadzisz & gromadzi- & gromadzić \\
\hline mieszczę & mieścisz & mieści- & mieścić \\
\hline$\alpha \pi \circ \delta i ́ \delta \omega$ & $\alpha \pi \circ \delta i ́ \delta \varepsilon 1 \varsigma$ & $\alpha \pi \mathrm{o} \delta 1 \delta-$ & $v \alpha \alpha \pi \mathrm{o} \delta i ́ \delta \omega$ \\
\hline$\lambda \varepsilon ı \tau о \nu \rho \gamma \omega ́$ & 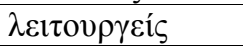 & $\lambda \varepsilon ı \tau \circ 0 \rho \gamma-$ & $v \alpha \lambda \varepsilon ı \tau о v \rho \gamma \omega ́$ \\
\hline 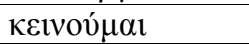 & 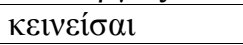 & 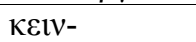 & $v \alpha \kappa \varepsilon 1 v o v ́ \mu \alpha \imath$ \\
\hline
\end{tabular}

W języku polskim urabianie formy bezokolicznika ciągłego bywa niekiedy bardziej skomplikowane ${ }^{15}$, ponieważ istnieje grupa czasowników rozszerzających podczas odmiany przez osoby temat o przyrostek -uj(e)-. Z kolei w czasie tworzenia bezokolicznika niedokonanego sufiks ten zostaje zastąpiony przez przyrostek $\quad-(0) w a-{ }^{16}$. Podobnego zjawiska nie da się odnaleźć w języku greckim, gdzie forma czasownika w trybie zależnym ciągłym jest zawsze równa formie teraźniejszej trybu orzekającego, a która nie przyjmuje sufiksów innych niż osobowe, np.:

Tabela 5. Bezokolicznik niedokonany czasowników na -uj(e)- ${ }^{17}$

\begin{tabular}{|l|l|l|l|}
\hline czas. w 1 os. sg. & czas. w 2 os. sg. & temat praes. & inf. / konstr. inf. \\
\hline domin-uj-ę & domin-uje-sz & domin- & domin-owa-ć \\
\hline powod-uj-ę & powod-uje-sz & powod- & powod-owa-ć \\
\hline
\end{tabular}

Dodatkowo, w języku polskim duża grupa czasowników prefiksalnych urabia bezokolicznik imperfektywny w sposób wtórny, a zatem nie $\mathrm{z}$ tematu niedokonanego, lecz dokonanego. Derywacja taka może przebiegać na dwa sposoby: (1) poprzez rozszerzenie niefinitywnego tematu prefiksalnego o przyrostek $-(\mathrm{y} / \mathrm{i} / \mathrm{e})$ wa- ${ }^{18}$ bądź (2) poprzez alternację samogłoski tematycznej $i / y$ do $a$. Do w ten sposób urabianych tematów bezokolicznikowych dodawany jest sufiks -ć/-c.

Tabela 6. Urabianie bezokolicznika niedokonanego $\mathrm{z}$ tematu dokonanego prefiksalnego ${ }^{19}$

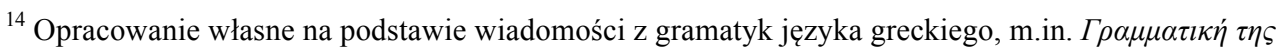

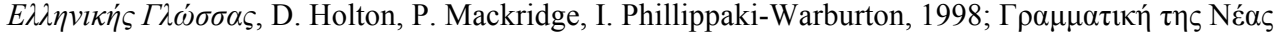

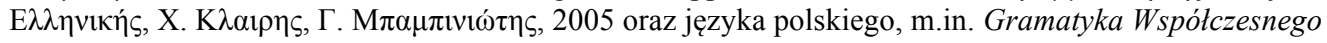
Języka Polskiego: Morfologia, [pod red.] Grzegorczykowa R., Laskowski R., Wróbel H., 1998, Podręczna gramatyka języka polskiego, A. Nagórko, 2010, Zarys gramatyki polskiej, A. Nagórko, 2000.

${ }^{15}$ Pominięta została tutaj kwestia urabiania tematów w sposób nieregularny poprzez wymianę stopy, jak np.: mam > mieć, biorę > brać.

${ }^{16}$ Należy rozróżnić między sobą czasowniki rozszerzające temat bezokolicznika imperfektywnego o sufiks (o)wa- od czasowników prefiksalnych dodających do tematu przyrostek -(y/i)wa-. Druga grupa zostanie omówiona w dalszej części pracy.

${ }^{17}$ Opracowanie własne na podstawie wiadomości z gramatyk języka polskiego, m. in. Gramatyka Współczesnego Języka Polskiego: Morfologia, [pod red.] R. Grzegorczykowa, R. Laskowski, H. Wróbel, 1998, Podręczna gramatyka języka polskiego, A. Nagórko, 2010, Zarys gramatyki polskiej, A. Nagórko, 2000.

${ }^{18}$ Pominięte zostają przypadki tego typu derywacji przez czasowniki nieprefiksalne, jak np.: dać > dawać.

${ }^{19}$ Opracowanie własne na podstawie wiadomości z gramatyk języka polskiego, m. in. Gramatyka Współczesnego Języka Polskiego: Morfologia, [pod red.] R. Grzegorczykowa, R. Laskowski, H. Wróbel, 1998, Podręczna gramatyka języka polskiego, A. Nagórko, 2010, Zarys gramatyki polskiej, A. Nagórko, 2000.
} 


\begin{tabular}{|l|l|l|l|}
\hline $\begin{array}{c}\text { inf. prefiks. } \\
\text { dok. }\end{array}$ & \multicolumn{1}{|c|}{$\begin{array}{c}\text { tem. prefiks. } \\
\text { dok. }\end{array}$} & $\begin{array}{c}\text { tem. prefiks. } \\
\text { ndk. }\end{array}$ & $\begin{array}{c}\text { inf. prefiks. } \\
\text { ndk. }\end{array}$ \\
\hline powstać & po-wsta- & po-wsta-wa- & powstawać \\
\hline odzyskać & od-zyska- & od-zysk-iwa- & odzyskiwać \\
\hline odpisać & od-pisa- & od-pis-ywa- & odpisywać \\
\hline podlać & pod-la- & pod-l-ewa- & podlewać \\
\hline przekształcić & prze-kształci- & prze-kształca- & przekształcać \\
\hline doprowadzić & do-prowadzi- & do-prowadza- & doprowadzać \\
\hline ocenić & o-ceni- & o-ceńa- & oceniać \\
\hline
\end{tabular}

Inną cechą niektórych czasowników polskich jest możliwość utworzenia w sposób fleksyjny bezokolicznika habitualnego, mogącego stać w opozycji do formy ciągłej (progresywnej). Np.:

$\begin{array}{lll}\text { czytać } & : & \text { czytywać } \\ \text { pisać } & : & \text { pisywać } \\ \text { mówić } & : & \text { mawiać } \\ \text { biec } & : & \text { biegać }\end{array}$

Jak widać na powyższych przykładach, sposób derywacji formy habitualnej jest identyczny ze sposobem urabiania tematu ciągłego od tematów prefiksalnych (poprzez przyrostek -(y/i)wa- lub alternację $y / i$ : a). Jednak forma ta jest używana stosunkowo rzadko (w funkcji habitualnej używany jest zwyczajny bezokolicznik niedokonany ciągły), a ponadto nie każdy czasownik polski może urobić oddzielną formę zwyczajową, jak np.:

$\begin{array}{lll}\text { kichać } & : & \varnothing \\ \text { brać } & : & \varnothing\end{array}$

Język grecki nie posiada form stojących ze sobą w opozycji pod względem habitualności w trybie zależnym i w obu kontekstach (progresywnym i habitualnym) użyty zostanie tryb zależny ciągły. Np.:

(4) Dzisiaj Kostas chce czytać przy śniadaniu.

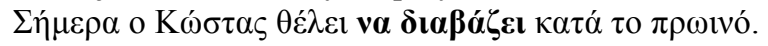

(5) Kostas ma zwyczaj czytywać/czytać przy śniadaniu.

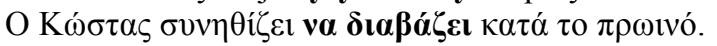

\subsection{Bezokolicznik dokonany a tryb zależny prosty}

$\mathrm{W}$ języku polskim jedną z dość produktywnych metod derywacji tematu perfektywnego z tematu niedokonanego jest dodanie do niego prefiksu. Problemem z tym związanym jest jednak to, że przedrostek niesie ze sobą nie tylko informację gramatyczną (aspektową), ale także semantyczną, która modyfikuje pierwotne znaczenie leksemu. $Z$ tego też powodu, jeden temat bazowy (temat imperfektywny prosty) może przyjmować więcej niż jeden prefiks:

\begin{tabular}{|c|c|c|c|}
\hline \multirow{4}{*}{ pisać } & \multirow{4}{*}{ : } & na-pisać prze-pisać & W-pisać \\
\hline & & wy-pisać & s-pisać \\
\hline & & od-pisać za-pisać & nad-pisać \\
\hline & & do-pisać o-pisać & roz-pisać \\
\hline
\end{tabular}

Poprzez łączenie form czasownikowych w pary aspektowe możliwe jest znalezienie dla bezokolicznika niezłożonego formy dokonanej przedrostkowej o identycznym bądź prawie identycznym znaczeniu. Np.:

$\begin{array}{lll}\text { kończyć } & : & \text { zakończyć } \\ \text { mieścić } & : & \text { pomieścić } \\ \text { regulować } & : & \text { uregulować }\end{array}$

W Języku greckim prefiksy nigdy nie niosą ze sobą żadnej informacji gramatycznej, jak np. aspektowej, lecz semantyczną. Za to są one nacechowane semantycznie i zmieniają one znaczenie podstawowe leksemu. Temat dokonany w większości przypadków urabiany jest regularnie (sygmatycznie) poprzez przyrostek - $\sigma-\mathrm{w}$ stronie czynnej oraz $-\theta-$ w stronie biernej (wraz z ich odmianami kontekstowymi). Dlatego też: 


\section{Investigationes Linguisticae, vol. XXVI}

Tabela 7 Urabianie tematu dokonanego greckich czasowników złożonych od $\gamma \rho \alpha ́ \varphi \omega-$ pisać $^{20}$

\begin{tabular}{|c|c|c|c|}
\hline con. imperfcv. & tem. imperfv. & tem. perfcv. & con. perfev. \\
\hline$v \alpha \gamma \rho \alpha ́ \varphi \omega$ & $\gamma \rho \alpha \varphi-$ & $\gamma \rho \alpha \psi-$ & $v \alpha \gamma \rho \alpha ́ \psi \omega$ \\
\hline$v \alpha$ vло $\gamma \rho \alpha \varphi \omega$ & $v \pi 0-\gamma \rho \alpha \varphi-$ & $v \pi 0-\gamma \rho \alpha \psi-$ & $v \alpha v \pi \mathrm{\alpha} \rho \rho \alpha \psi \omega$ \\
\hline$v \alpha \kappa \alpha \tau \alpha \gamma \rho \alpha \dot{\varphi} \omega$ & $\kappa \alpha \tau \alpha-\gamma \rho \alpha \varphi-$ & $\kappa \alpha \tau \alpha-\gamma \rho \alpha \psi-$ & $v \alpha \kappa \alpha \tau \alpha \gamma \rho \alpha ́ \psi \omega \omega$ \\
\hline$v \alpha \varepsilon \pi \imath \gamma \rho \alpha ́ \varphi \omega$ & $\varepsilon \pi t-\gamma \rho \alpha \varphi-$ & $\varepsilon \pi t-\gamma \rho \alpha \psi-$ & $v \alpha \varepsilon \pi \imath \gamma \rho \alpha ́ \psi \omega$ \\
\hline
\end{tabular}

Dla porównania, polski odpowiednik powyższej tabeli wygląda następująco:

Tabela 8. Urabianie tematu niedokonanego i dokonanego dla czasowników złożonych od czasownika bazowego pisac ${ }^{21}$

\begin{tabular}{|l|l|l|l|}
\hline inf./con. imperfcv. & \multicolumn{1}{|c|}{ tem. imperfv. } & \multicolumn{1}{|c|}{ tem. perfcv. } & inf./con. perfcv. \\
\hline pisać & pis- & na-pis- & napisać \\
\hline podpisywać & pod-pis-ywa- & pod-pis- & podpisać \\
\hline spisywać & s-pis-ywa- & s-pis- & spisać \\
\hline tytułować & tytuł-owa- & za-tytuł-owa- & zatytułować \\
\hline
\end{tabular}

W języku polskim, podobnie do języka greckiego, aspekt dokonany może być wyrażany nie poprzez prefiks lecz sufiks. Dotyczy to czasowników momentalnych (punktowych), które mogą jednak złożyć się na serię takich zdarzeń (iteratywność) (Nagórko, 2010). Tworzone są za pomocą przyrostka dokonanego -ną-, dodawanego do tematu ciągłego (iteratywnego). Np.:

$\begin{array}{lll}\text { unika-ć } & : & \text { unik-ną-ć } \\ \text { znika-ć } & : & \text { znik-ną-ć } \\ \text { stuka-ć } & : & \text { stuk-ną-ć }\end{array}$

Część czasowników greckich i polskich tworzą tematy dokonane bardziej lub mniej regularnie poprzez wymiany stóp bądź całych tematów. Regularną wymianę stopy w języku greckim można zaobserwować u czasowników greckich o tematach zakończonych na spółgłoski płynne - $\lambda-,-\rho-$ oraz nosowe $-\mu-,-\nu-$. W pierwszym przypadku, przy obecnych prawach fonetycznych, zmiana tematu może następować tylko i wyłącznie na płaszczyźnie graficznej, gdzie podwójna spółgłoska (wymawiana jednak krótko i pojedynczo) $-\lambda \lambda$ - lub - $\rho \rho$ - wymienia się na spółgłoskę pojedynczą $-\lambda$ , - $\rho-$, bądź przez graficzne skrócenie podwójnej spółgłoski płynnej i wymianie samogłoski tematycznej $-\varepsilon-\mathrm{w}$ dyftong $-\varepsilon l$-. Taka sama wymiana samogłoski tematycznej zachodzi w przypadku czasowników o temacie zakończonym na spółgłoskę nosową (pierwotną). Oprócz tego tworzą one temat dokonany asygmatycznie (bez markera -s-) (Klairis, Babiniotis 2005, 510), np.:

\begin{tabular}{|c|c|c|}
\hline$\alpha \kappa \alpha \tau \alpha \beta \alpha ́ \lambda \lambda \omega$ & : & $v \alpha \kappa \alpha \tau \alpha \beta \alpha ́ \lambda \omega$ \\
\hline$v \alpha \sigma \tau \dot{\varepsilon} \lambda v \omega\left({ }^{*} \sigma \tau \dot{\varepsilon} \lambda \lambda \omega\right)$ & : & $\nu \alpha \sigma \tau \varepsilon i ́ \hat{\lambda} \omega$ \\
\hline 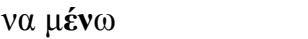 & & $v \alpha \mu \varepsilon i ́ v \omega$ \\
\hline
\end{tabular}

W języku polskim wymiany samogłoskowej można by się doszukiwać wśród czasowników nieregularnych typu: zabierać : zabrać. Temat ten jednak wymaga wnikliwszych badań w przyszłości.

Ostatnim typem par aspektowych są nieregularne czasowniki polskie i greckie, które cechują się wymianą tematów (tzw. tematy suplementywne), wśród których trudno dopatrywać się regularnych zabiegów fleksyjnych/derywacyjnych ${ }^{22}$. Przykładami takich czasowników są w języku polskim: brać : wziąć, wchodzić : wejść, spać : zasnąć, w języku greckim: va $\lambda \alpha \mu \beta \dot{\alpha} v \omega: v \alpha$

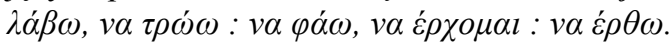

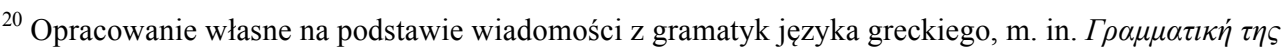

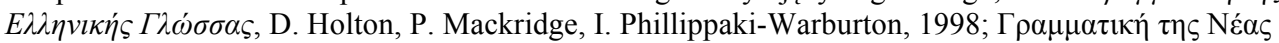

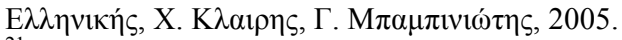

${ }^{21}$ Opracowanie własne na podstawie wiadomości z gramatyk języka polskiego, m. in. Gramatyka Współczesnego Języka Polskiego: Morfologia, [pod red.] R. Grzegorczykowa, R. Laskowski, H. Wróbel, 1998, Podręczna gramatyka języka polskiego, A. Nagórko, 2010, Zarys gramatyki polskiej, A. Nagórko, 2000.

${ }^{22}$ Choć z punktu historycznego mogą się czasem wywodzić z tego samego rdzenia, obecna ich formy różnią się w znacznym stopniu.
} 


\subsection{Tryb zależny perfectum}

W nowogreckim trybie zależnym można wyróżnić jeszcze trzeci rodzaj aspektu, tzw. perfectum (Mackridge, 2004). Tworzony jest on analitycznie poprzez partykułę $v \alpha$, czasownik pomocniczy $\dot{\varepsilon} \chi \omega$ - mieć, który odmienia się przez osoby i liczby, oraz czasownik w formie „bezokolicznika”, którego budowa została przedstawiona we wcześniejszej części pracy. W języku polskim nie istnieje ani analityczna, ani morfologiczna forma dla tej kategorii gramatycznej, gdyż perfekt nie został w nim w żaden sposób zgramatykalizowany.

Zagadnienie realizacji informacji niesionych przez grecką konstrukcję koniunktywną w perfectum wymaga szczegółowych badań w przyszłości. Nie jest ono rozwijane w niniejszej pracy.

\section{Użycie bezokolicznika niedokonanego i dokonanego w języku polskim a użycie konstrukcji bezokolicznikowej ciągłej i prostej w języku nowogreckim}

W języku polskim i nowogreckim w konstrukcjach zdaniowych konotujących bezokolicznik/tryb warunkowy, może on przyjąć wartość aspektową dokonaną bądź niedokonaną (prostą bądź ciągłą), w zależności od kontekstu semantycznego oraz składniowego. Zagadnienie aspektu zostało dokładniej omówione we wcześniejszej części pracy (2.1. Aspekt).

\subsection{Bezokolicznik niedokonany a tryb zależny ciągły}

Funkcje bezokolicznika niedokonanego w języku polskim oraz koniunktiwusa ciągłego w języku nowogreckim mogą pełnić następujące funkcje:

- habitualną lub iteratywną:

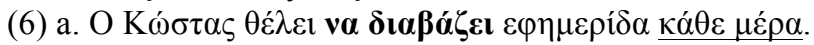

b. Kostas chce czytać codziennie gazetę.

- inchoatywną:

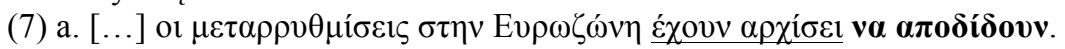

b. [...] reformy w Strefie euro zaczynają przynosić rezultaty.

- terminatywną:

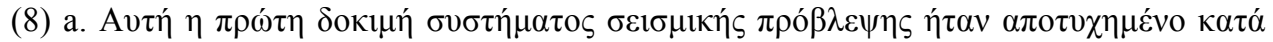

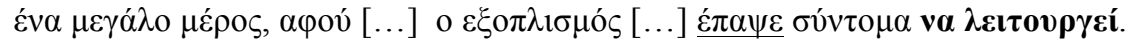

b. Pierwsza próba systemu przewidywania trzęsień zimie nie powiodła się $\mathrm{w}$ dużym stopniu, $[\ldots]$ ponieważ urządzenia, $[\ldots]$ nagle przestały dzialać.

- umiejętnościową/zdolnościową:

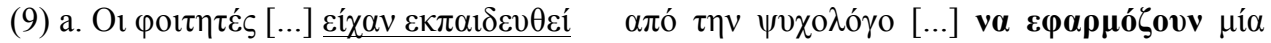

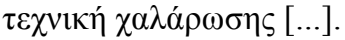

b. Pani psycholog nauczyła studentów [...] stosować pewną technikę relaksacyjną [...].

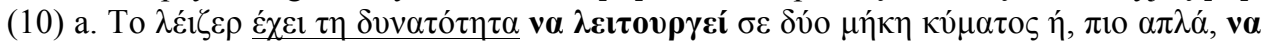

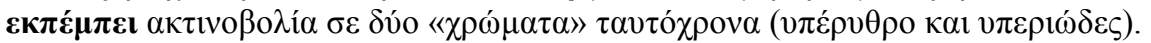

b. Laser może pracować w 2ch długościach fal lub, mówiąc prościej, wysylać promieniowanie w dwóch kolorach (podczerwieni i nadfiolecie).

- duratywną:

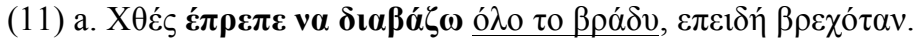

b. Wczoraj musiałem czytać cały wieczór, ponieważ padało.

- $\quad$ progresywną:

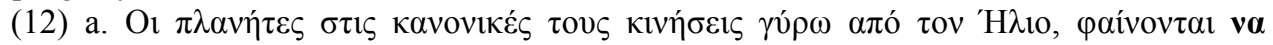

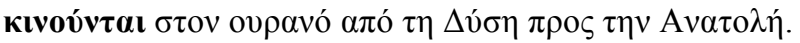

b. Planety w swoim standardowym ruchu dookoła Słońca wydają się poruszać z zachodu na wschód.

Jak widać, funkcje pełnione przez polski bezokolicznik niedokonany i grecki tryb zależny, pokrywają się. O podobnej zbieżności funkcyjnej nie można mówić w przypadku np. języka angielskiego, w którym habitualność i wielokrotność wyrażana jest poprzez formy proste (aspekt 


\section{Investigationes Linguisticae, vol. XXVI}

dokonany). Spowodowane to jest tendencją do wyrażania tejże kategorii przez formę najmniej nacechowaną (Comrie 1976, Dahl 1985), którą w języku angielskim jest czysty temat czasownika (aspekt dokonany), a w języku polskim i nowogreckim forma ciągła urabiana $\mathrm{z}$ tematu praes.

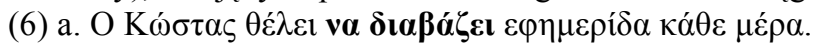

b. Kostas chce czytać codziennie gazetę.

c. Kostas wants to read (to be reading) a newspaper daily.

\subsection{Bezokolicznik dokonany a tryb zależny prosty}

Podczas odwoływania się do funkcji aspektu dokonanego, najczęściej mówi się o rezultatywności (skończoności) danej czynności, która to zmienia stan rzeczywistości poza językowej. Nacisk kładzie się wówczas nie na etapy (procesy) zachodzących zmian, lecz na skutek wynikający z jej zajścia:

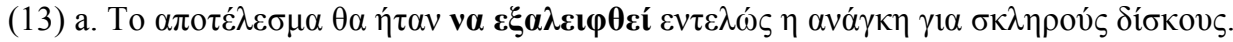

b. W efekcie może zniknąć całkowicie zapotrzebowanie na twarde dyski.

A zatem stan początkowy ,zapotrzebowanie” zmieni się ,,zniknie”, w czego efekcie owego zapotrzebowania nie będzie.

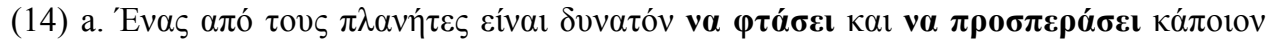
$\alpha \dot{\lambda} \lambda \mathrm{o}$.

b. Jedna planeta jest w stanie dogonić i wyprzedzić inną.

Mianowicie, można wyróżnić łącznie trzy stany: 1 - gdy pierwsza planeta jest przed drugą (stan początkowy dla obu czynności), 2 - gdy druga planeta dogania, zrównuje się z pierwszą, oraz 3 gdy druga planeta znajduje się przed pierwszą planetą.

Koleją własnością czasowników przybierających formy dokonane, jest ich semelfaktywność (jednorazowość). Oznacza to, że czynność ta nie tylko jest punktowa (momentalna) czy teliczna, ale ma miejsce tylko jeden raz. Np.:

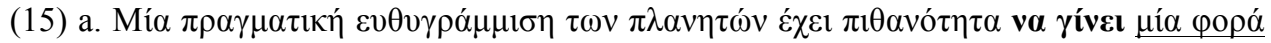

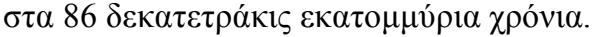

b. Ustawienie się wszystkich planet $\mathrm{w}$ jednej linii może się zdarzyć raz na 86 septylionów lat.

Postać dokonana przyjmowana jest także w przypadku czynności parokrotnych, bądź wielokrotnych, gdy jednak ich ilość jest ściśle określona bądź zamknięta. Nie są to czynności zwyczajne, zachodzące często i/lub regularnie.

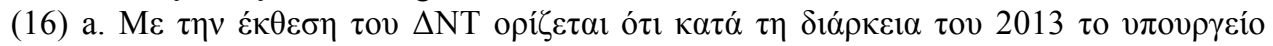

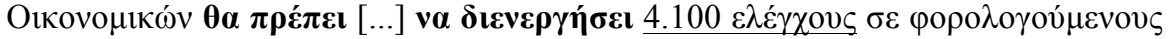

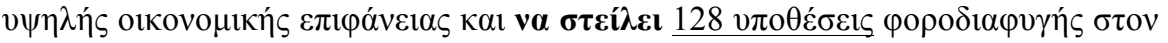
$\varepsilon 1 \sigma \alpha \gamma \gamma \varepsilon \lambda \varepsilon \dot{\varepsilon} \alpha$.

b. Z raportu Międzynarodowego Funduszu Walutowego wynika, że w 2013 roku Ministerstwo Finansów będzie musiało [...] przeprowadzić 4100 dochodzeń podatkowych wśród bogatszej części społeczeństwa i wysłać do prokuratury 128 zawiadomień o niezapłaceniu podatków.

A zatem czynność przeprowadzania dochodzenia zostanie podjęta 4100 razy, a wysyłania zawiadomienia 128 razy.

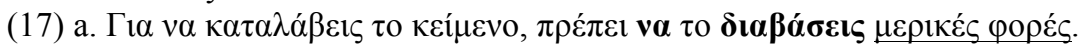

b. Aby zrozumieć ten tekst, musisz go przeczytać parę razy.

Jak widać powyżej, semelfaktywność nie musi być związana ze ściśle sprecyzowaną ilością zajść danej czynności, lecz wystarczy, że zostanie ona zamknięta, ograniczona.

\subsection{Różnice aspektowe w użyciu polskiego bezokolicznika i greckiego trybu zależnego}

W próbie 112 zdań greckich oraz ich tłumaczeń na język polski w dziewiętnastu z nich ta sama informacja była realizowana w sposób aspektualnie różny. Dało to łącznie dwadzieścia cztery bezokoliczniki i koniunktywy, w których formy aspektowe się nie pokrywają. Różnice te mogą mieć dwojaki charakter: (a) gdy w języku polskim używany jest aspekt dokonany język grecki realizuje ową informację przy użyciu formy niedokonanej (6 zdań), (b) gdy w języku polskim używany jest aspekt niedokonany w greckim występuje forma dokonana (13 zdań). 


\subsubsection{Bezokolicznik dokonany a tryb zależny ciągły}

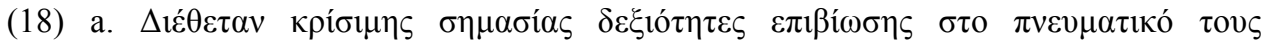

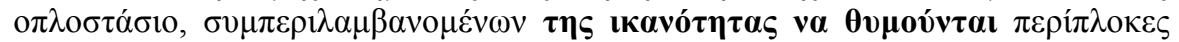

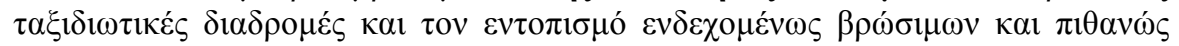

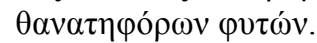

b. Dysponowali szczególnie ważnymi zdolnościami umysłowymi umożliwiającymi przeżycie, jak na przykład umieli zapamiętać skomplikowane drogi oraz lokalizację ewentualnych jadalnych i trujących roślin.

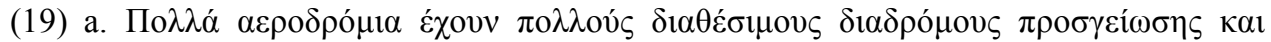

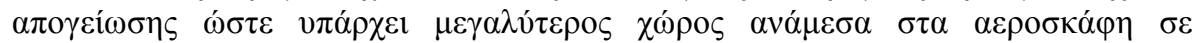

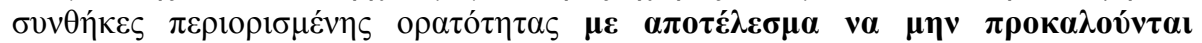

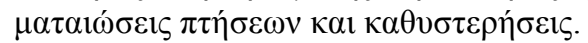

b. Wiele lotnisk ma zapasowe pasy startowe, by zrobić więcej miejsca pomiędzy samolotami w przypadku ograniczonej widoczności, a w wyniku czego nie doprowadzić do anulacji i opóźnień lotów.

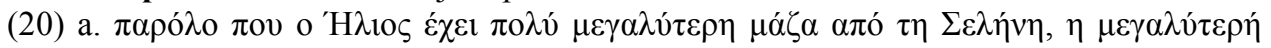

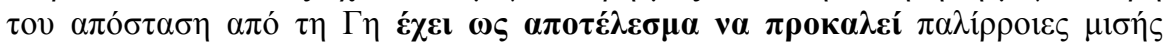

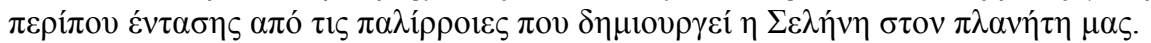

b. Pomimo, że Słońce ma dużo większą masę od Księżyca, na skutek dużo większej odległości od Ziemi, jest w stanie wywołać pływy o połowę mniejsze od pływów wytwarzanych na naszej planecie przez Księżyc.

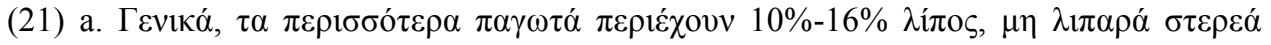

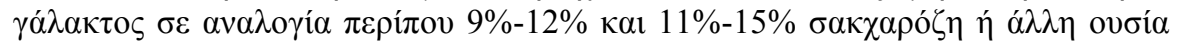

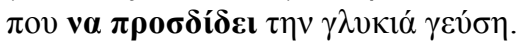

b. Ogólnie mówiąc, lód zazwyczaj zawiera 10-16\% tłuszczu, nietłuszczowe ciała stałe mleka w proporcjach 9-12\% i 11-15\% sacharozy lub innej substancji, która [może] nadać słodkiego smaku.

W pierwszych dwóch zdaniach (18 i 19) rolę nadrzędnika greckiego koniunktiwusa stanową

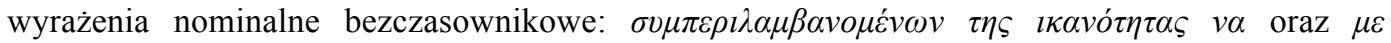

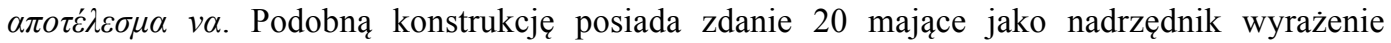
frazeologiczne $\dot{\chi} \chi \varepsilon l \omega \varsigma \alpha \pi o \tau \dot{\varepsilon} \lambda \varepsilon \sigma \mu \alpha v \alpha$. Fakt ten jednak nie ma wpływu na przyjmowany w zdaniu aspekt trybu zależnego, ponieważ można je również zaobserwować z dokonanym trybem warunkowym:

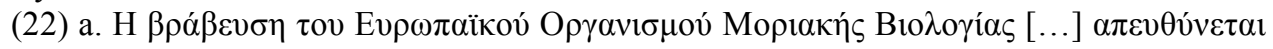

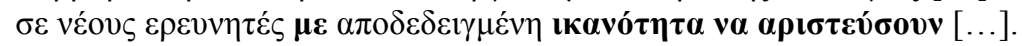

b. Nagroda Europejskiej Organizacji Biotechnologii Molekularnej [...] jest skierowana do młodych naukowców, którzy mają możliwości, by znaleźć się w światowej czołówce $[\ldots]$.

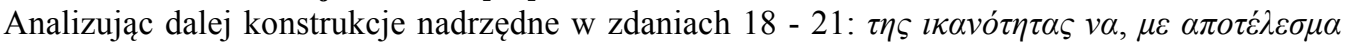

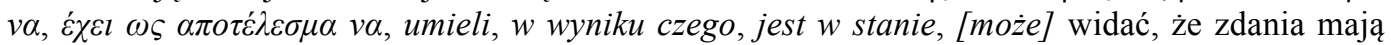
charakter rezultatywny, a zatem nakierowane są na zajście, zakończenie czynności, czego następstwem jest zmiana stanu. Tłumaczyłoby to użycie aspektu dokonanego w języku polskim. Jeśli z kolei spojrzeć na te zdania całościowo, można zauważyć, że zdania te wyrażają właściwości i/lub cechy danych obiektów bądź zjawisk. Tłumaczyłoby to użycie form ciągłych w języku greckim. Wynika $\mathrm{z}$ tego, że różnice aspektualne pomiędzy tymi zdaniami spowodowane są różnymi punktami widzenia osoby mówiącej na zjawisko, które może być rozumiane jako rezultatywne, wywołujące daną zmianę stanu każdorazowo, gdy zajdzie, bądź jako swego rodzaju zdolność (por. czasowniki umiejętnościowe/zdolnościowe, 4.1), zwyczajowość, wielokrotność, generatywność jego zajścia.

Ostatnim zdaniem z tej grupy jest:

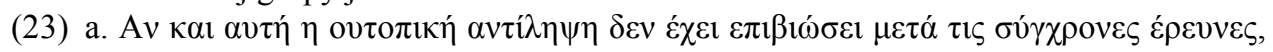

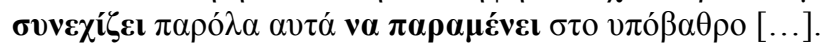

b. Chociaż temu idealistycznemu przekonaniu nie udało się przetrwać próby obecnych badań, to mimo to zdołala pozostać u podstaw [ideologicznych] [...].

*c. Chociaż temu idealistycznemu przekonaniu nie udało się przetrwać próby obecnych badań, to mimo to wciąż pozostaje u podstaw [ideologicznych] [...].

Oddzieliłem je specjalnie od pozostałych, ponieważ różnica aspektualna miedzy wersją grecką i polską oparta jest przede wszystkim na leksyce i niemożliwości w miarę dokładnego (z 


\section{Investigationes Linguisticae, vol. XXVI}

zachowaniem konstrukcji bezokolicznikowej) oddania greckiego oryginału. Grecki czasownik

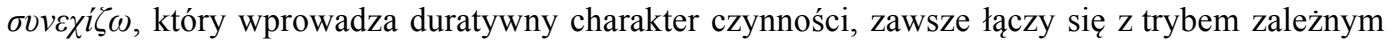
ciągłym (Vogiatzidou, Demiri-Prodromidou, Nikolaidou-Nestora, Tryfona-Antonopopoulou, 2000). Jeśli przetłumaczy się grecki tryb zależny przy pomocy przysłówka wciąz, to wówczas wprowadza on także formę ciągłą (tu. teraźniejszą).

\subsubsection{Bezokolicznik niedokonany a tryb zależny prosty}

Różnica w użyciu bezokolicznika niedokonanego i koniunktiwusa prostego występuje statystycznie (prawie trzykrotnie) częściej aniżeli ta opisana w poprzedniej części pracy. Podzieliłem te zdania w pięć grup:

- o zamkniętym przedziale czasowo-przestrzennym

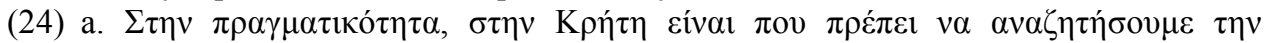

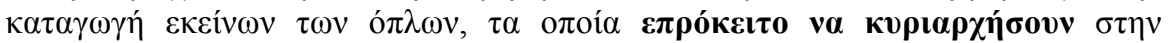

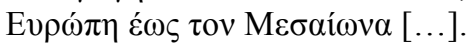

b. Tak naprawdę to na Krecie należy się doszukiwać pochodzenia tej broni, która wydawała się dominować $w$ Europie do czasów Średniowiecza [...].

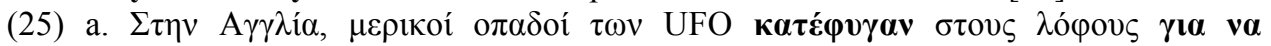

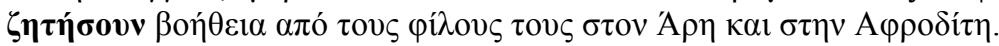

b. W Anglii niektórzy zwolennicy UFO wyszli na pagórki prosić o pomoc swoich przyjaciół z Marsa i Wenus.

Jak widać, obie czynności dominować oraz prosić są nierozerwalnie związane z pewnym konkretnym okresem w czasie oraz miejscem w przestrzeni. W zdaniu 24 jest to okres od starożytności do średniowiecza, w drugim jest pewien konkretny (bliżej nieokreślony) dzień, który jednak się już zakończył. Język polski ma tendencję do traktowania przedziałów czasowych jako wskaźnik duratywności, stad użyta jest forma ciągła - aż do średniowiecza można obserwować dane zjawisko, było ono długotrwałe, zwyczajowe i powtarzalne; Anglicy którzy wyszli na pagórek spędzili na nim jakiś czas (przykładowo cały dzień), w czasie którego wykonywana była czynność proszenia. Z kolei użytkownicy języka greckiego traktują owy przedział jako jeden niepodzielny punkt w czasie, który nawet jeśli posiada strukturę wewnętrzną, to jest ona nieistotna.

- $\quad$ imperfectivum tantum i perfectivum tantum

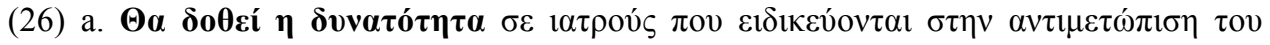

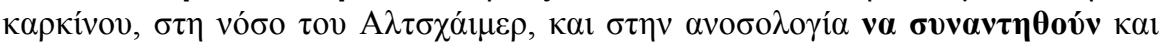

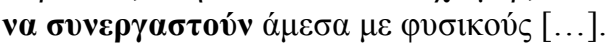

b. Lekarze, którzy specjalizują się w zwalczaniu raka, w chorobie Alzheimera i w immunologii, będą mieli możliwość spotkać się i bezpośrednio wspólpracować z fizykami.

*c. Lekarze, którzy specjalizują się w zwalczaniu raka, w chorobie Alzheimera i w immunologii, będą mieli możliwość spotkać się i bezpośrednio podjąć współpracę z fizykami.

Jak widać, polskiemu czasownikowi wspótpracować można przypisać niedokonaną wartość aspektową. Trudno jest też utworzyć od niego formę dokonaną ${ }^{23}$, co może wynikać z rodzaju czynności przez niego reprezentowaną (kojarzącą się raczej z czynnością trwającą przez pewien okres czasu (duratywną), aniżeli jednorazową, punktową). Jeżeli przyjrzymy się zdaniu 26 c., w którym czasownik wspótpracować został zastąpiony wyrażeniem podejmować wspótpracę, widoczne jest, że w języku polskim, podobniej jak w greckim, użyty jest aspekt dokonany. Grecki

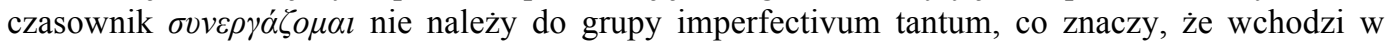
opozycję aspektową niedokonay : dokonany ( $\alpha \alpha \varepsilon \rho \gamma \alpha ́ \zeta o \mu \alpha \iota: v \alpha \varepsilon \rho \gamma \alpha \sigma \tau \omega ́)$.

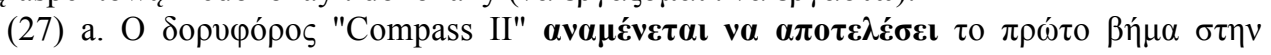

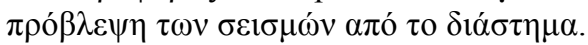

b. Satelita Compass II powinien stanowić pierwszy krok w kierunku przewidywania trzęsień ziemi z kosmosu.

\footnotetext{
${ }^{23}$ Dla czasownika wspótpracować można utworzyć formę dokonaną powsótpracować, jednak jest ona bardzo mocno nacechowana i użyta może być tylko w nielicznych i konkretnych sytuacjach. Dlatego też postanowiłem uznać za osobne pary aspektowe współpracować : powspótpracować i współpracować : Ø.
} 
*c. Satelita Compass II należy uznać za pierwszy krok w kierunku przewidywania trzęsień ziemi z kosmosu.

Podobnie do wcześniejszego przykładu, czasownik stanowić nie posiada swojego dokonanego odpowiednika $^{24}$. Szukając takiego polskiego odpowiednika zdaniowego, by zamienić stanowić innym czasownikiem wchodzącym w opozycję aspektową (tutaj jest to czasownik uznawać), użyta zostaje forma dokonana bezokolicznika, analogicznie do greckiego trybu zależnego.

W języku greckim również można odnaleźć czasowniki, które nie urabiają form dokonanych (imperfectiva tantum) lub niedokonanych (perfectiva tantum). Grupa ta jest jednak nieliczna $\mathrm{i}$

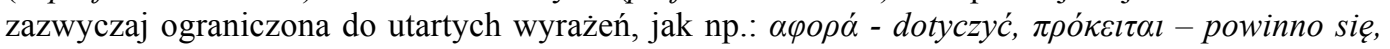
chodzi o, $\kappa \dot{v} v \omega-$ robię, $\xi \dot{c} \rho \omega-$ wiem, umiem. (Mackridge, 2004).

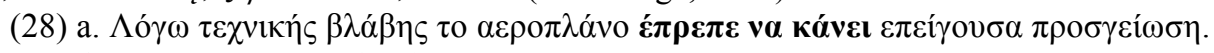

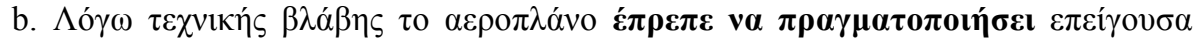
$\pi \rho$ $о \gamma \varepsilon i ́ \omega \sigma \eta$.

c. Z powodów technicznych samolot musial wylądować awaryjnie.

Grecki czasownik $\kappa o ́ v \omega-r o b i c ́$, wykonywać jest jednym z przedstawicieli grupy czasowników imperfectiva tanta i nie urabia formy dokonanej. Konstrukcja koniunktywna w zdaniu 28 a. jest konstrukcją niedokonaną. Jeżeli czasownik ten jednak zostanie zastąpiony czasownikiem $\pi \rho \alpha \gamma \mu \alpha \tau o \pi o \imath \omega ́-w y k o n y w a c ́$, to wówczas przyjmuje on formę dokonaną.

- $\quad$ rezultatywne vs. generyczne

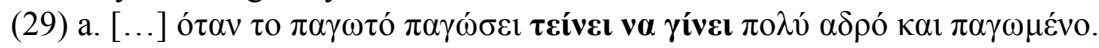

b. [...] gdy lód zamarza, ma tendencję nabierać nieregularnych kształtów i stawać się bardzo zimny.

W powyższych przykładach natykamy się na sytuację podobną do tej, ze zdań 18-21, jednak o odwrotnej wartościowości aspektowej. Tutaj to w języku greckim tryb zależny jest dokonany, polski bezokolicznik zaś jest niedokonany. Świadczy to o dość dużej swobodzie obu języków do „żonglowania” aspektualnymi formami czasowników, w zależności od intencji osoby mówiącej.

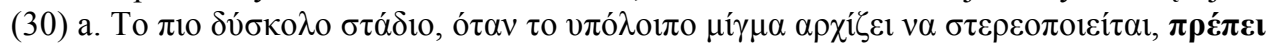

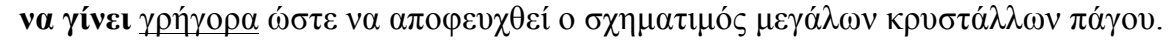

b. Najtrudniejsza faza, kiedy reszta mieszaniny zaczyna krzepnąć, musi przebiegać szybko, żeby uniknąć wykształcenia się dużych kryształków lodu.

*c. Najtrudniejsza faza, kiedy reszta mieszaniny zaczyna krzepnąć, musi przebiegać szybko, żeby uniknąć wykształcenia się dużych kryształków lodu.

Chociaż zdanie to można zanalizować w sposób podobny do 28 , warto tutaj zwrócić uwagę na przysłówek $\gamma \rho \eta ́ \gamma o \rho \alpha$ - szybko, który można traktować jako determinant aspektu dokonanego, ograniczającego ją do jednego punktu, pomijając jej wewnętrzną strukturę i procesualność (etapowość) zachodzenia, do tego koncentrując się na rezultacie $\omega ́ \sigma \tau \varepsilon v \alpha \alpha \pi o \varphi \varepsilon v \chi \theta \varepsilon i ́$ o $\sigma \chi \eta \mu \alpha \tau i \mu o ́ \varsigma$ $\mu \varepsilon \gamma \dot{\alpha} \lambda \omega v \kappa \rho v \sigma \tau \dot{\alpha} \lambda \lambda \omega v$ $\pi \dot{\alpha} \gamma o v$. Jak widać w 29 c., w języku polskim możliwe jest również zastosowanie formy przebiec porzucając generyczność procesu na rzecz jej rezultatywności.

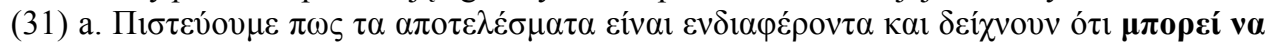

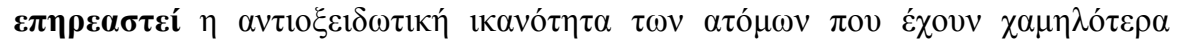

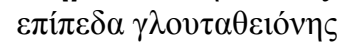

b. Wierzymy, że wyniki są interesujące i pokazują, że można wpływać na zdolności przeciwutleniające u ludzi, którzy mają obniżony poziom glutationu.

*c. Wierzymy, że wyniki są interesujące i pokazują, że można wpłynąć na zdolności przeciwutleniające u ludzi, którzy mają obniżony poziom glutationu.

Patrząc na zdanie 30 b. i c. można zauważyć, że, podobnie jak w zdaniu 29, możliwe jest użycie form bezokolicznika dokonanego i niedokonanego w zależności od intencji osoby mówiącej - czy nacisk kładziony jest na powtarzalność (możliwość powtarzania) generatywny charakter czynności, czy też na jej rezultat.

- $\quad$ aspekt zerowy ${ }^{25}$ - używany jest w momencie, gdy czynność nie odnosi się do żadnego okresu czy też punktu w czasie bądź przestrzeni, nie odwołuje się do determinantów aspektowych (jak np. powtarzalność, długotrwałość) oraz przy wykluczeniu specjalnych intencji osoby mówiącej. W języku polskim rolę aspektu zerowego (mniej nacechowanego) pełni aspekt niedokonany, w greckim dokonany.

\footnotetext{
${ }^{24}$ Wszystkie formy przedrostkowe zmieniają znaczenie podstawowe leksemu STANOWIĆ.

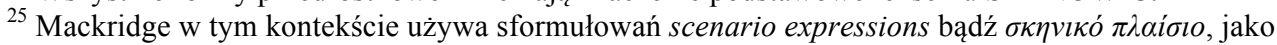
odniesień do ciągłości, powtarzalności, itd. czynności (2004, 185-188).
} 


\section{Investigationes Linguisticae, vol. XXVI}

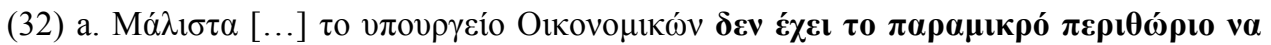

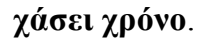

b. Oczywiście, [...] Ministerstwo Finansów nie może tracić czasu.

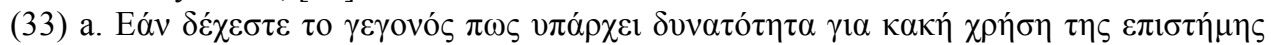

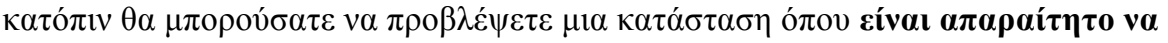

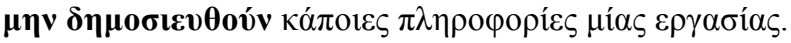

b. Jeśli przyznacie, że możliwe jest wykorzystanie badań naukowych do złych celów, wówczas możecie sobie wyobrazić sytuację, gdy jest konieczne, by nie publikować niektórych informacji.

Grupa ta jest najszersza i można do niej zaliczyć także zdania rezultatywno-generyczne 29 i 30, w których wersja c. jest bardziej nacechowana (wyraża konkretne intencje i punkt widzenia osoby mówiącej), a wersja b. mniej. W zdaniu 28 aspekt niedokonany jest zdeterminowany przez frazę nadrzędną mieć tendencję. Zastąpiwszy ją jednak np. czasownikiem może otrzymujemy:

(28) *c. [...] gdy lód zamarza, może nabierać nieregularnych kształtów i stawać się bardzo zimny.

*d [...] gdy lód zamarza, może nabrać nieregularnych kształtów i stać się bardzo zimny.

Ostatnim omówionym przypadkiem różnic aspektualnych w języku polskim oraz nowogreckim jest zdanie:

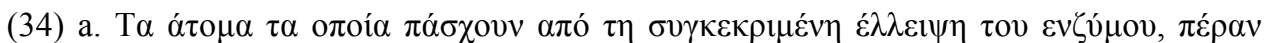

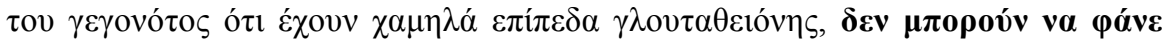

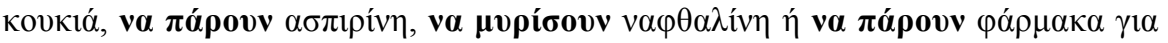

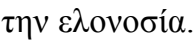

b. Osoby cierpiące na szczególny niedobór enzymu, pomimo, że mają niski poziom glutationu, nie mogą jeść bobu, brać aspiryny, wdychać naftaliny czy zażywać lekarstw na malarię.

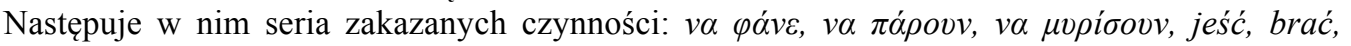
wdychać, zażywać. O ile w języku polskim użycie aspektu niedokonanego wydaje się oczywiste, gdyż wyrażany jest zakaz ogólny, generyczny - czynności te są zakazane całkowicie - mianowicie nigdy nie mogą dane osoby jeść, brać, wdychać czy zażywać wymienionych substancji, o tyle tego samego aspektu oczekiwalibyśmy również w greckim. Różnicę tę można tłumaczyć właśnie poprzez tezę aspektu zerowego, nastawieniu na jednokrotność wydarzenia (nie mogą ani razu ${ }^{26}$ zjeść bobu, itd.), bądź emfazą na rezultat czynności (np. powikłania, śmierć).

\subsection{Związek aspektu i określoności-nieokreśloności zdania}

[1]"Ciekawy jest natomiast zwiąek z określonościa i co za tym idzie - z policzalnościa. Zwraca się uwage na to, że języki z rozwiniętym systemem aspektu i przypadków gramatycznych nie potrzebuja rodzajnika, by wyrazić charakter obiektu nazwanego rzeczownikiem, por. szukać mieszkania (D.) i znaleźć mieszkanie (B.), prosić pomocy (D.) $i$ wyprosić pomoc (B.), bronić doktoratu (D.) $i$ obronić doktorat (B.). Forma $n d k w$ połaczeniu z dopetniaczem ma znaczenie nieokreślone, $w$ przeciwieństwie do czasownika dk z rzadem biernikowym (np. dopiero po udanej obronie praca zastuguje na miano doktoratu). Dopetnienie przy czasowniku ndk pisać ksiażki jest nieokreślone co do faktycznej liczby, co je zbliża do niepoliczalnych nazw substancji, jak pić piwo. Natomiast użycie dk napisać pociaga za soba informację o liczbie: napisać cztery ksiązki/kilka książek. Analogicznie dk wypić piwo informuje o tym, że całe piwo zostało wypite. W języku mającym rodzajniki różnica ta znajdzie swój wyraz w przekładzie: Pił piwo - Er trank Bier/ / Wypit piwo - Er trank das Bier” (Nagórko 2010, 141).

W powyżej przedstawionym fragmencie pojawia się twierdzenie na temat współzależności różnych kategorii gramatycznych (aspektu, określoności, przypadka), które nie zawsze zostały zgramatykalizowane w różnych językach (np. kategoria określoności, która nie posiada własnego wykładnika gramatycznego w języku polskim). Jednocześnie, zaobserwowaną przez Nagórko zależność warto skonfrontować $\mathrm{z}$ innymi systemami językowymi, co ewentualnie by ją potwierdziło lub obaliło jako twierdzenie o charakterze uniwersalnym.

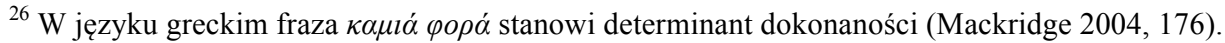


Język nowogrecki posiada system aspektualny, bardzo uproszczony system przypadków gramatycznych oraz rodzajnikowy (rodzajniki określone w obu liczbach i nieokreślony w liczbie pojedynczej). W czasie analizy aspektu przyjmowanego przez tryb zależny, nie da się potwierdzić tezy wysuniętej przez Nagórko, ponieważ, o ile w przypadku zdań o dopełnieniu określonym (poprzedzonych rodzajnikiem określonym) dominuje użycie trybu zależnego prostego, o tyle stwierdzenie to pozostaje prawdziwe również w przypadku zdań o dopełnieniu nieokreślonym (z rodzajnikiem nieokreślonym bądź zerowym).

Tabela 9. Związek aspektu i wartości określoności w zdaniach greckich ${ }^{27}$

\begin{tabular}{|l|l|l|}
\hline & dop. okreslone & dop. nieokreślone \\
\hline tryb zależny prosty & 23 & 24 \\
\hline tryb zależny ciągły & 5 & 8 \\
\hline
\end{tabular}

Jak widać stosunek występowania trybu zależnego prostego z dopełnieniem określonym i nieokreślonym balansuje $\mathrm{w}$ tych samych granicach $(23: 24)$, podobnie jak stosunek występowania z nimi trybu zależnego ciągłego w funkcji bezokolicznika (5:8).

W przypadku języka polskiego, dokonanie takiej analizy nie jest tak proste, jak w przypadku języka greckiego, a wyniki nie są w pełni jednoznaczne, ponieważ kategoria określoności nie jest zgramatykalizowana. Co za tym idzie, problematyczne jest odgraniczenie form nieokreślonych, wyrażanych przypadkiem gramatycznym dopełnienia (o ile faktycznie takie zjawisko ma miejsce), od rekcji czasownika. Dodatkowych problemów dostarczają konstrukcje syntaktyczne, jak np. negacja czasownika modyfikująca jego rekcję czy pozostałości dopełniacza cząstkowego.

$\mathrm{Na}$ uwagę zasługują tutaj frazy takie jak np. unikać anulacji (Gen.), wywołać pływy (Acc.), doszukiwać się pochodzenia(Gen.) (czegoś), dokonywać analizy (Gen.), u których to przypadek, w którym stoi dopełnienie nie zmienia się wraz ze zmianą aspektu: uniknać anulacji (Gen.), wywoływać plywy (Acc..), doszukać się pochodzenia (Gen.), dokonać analizy (Gen.). A zatem relacja orzeczenie-dopełnienie oparta jest na rekcji czasownika, która pozostaje niezależna od aspektu gramatycznego.

Warto zwrócić również uwagę, że związek rządu miedzy orzeczeniem a dopełnieniem nie ulega modyfikacji podczas frazowego nadania wartości określonej bądź nieokreślonej. Np.:

(za)stosować technikę : (za)stosować jakąś technikę : (za)stosować tę technikę

(o)publikować pracę : (o)publikować jakąś pracę : (o)publikować tę pracę

usuwać informacje : usuwać jakieś informacje : usuwać tę informację

usunąc informacje : usunąć jakieś informacje : usunąć te informacje

Na podstawie powyższych przykładów, trudno jest się dopatrywać związku pomiędzy formą aspektową czasownika a formą dopełnienia, tak samo jak między przypadkiem gramatycznym rzeczownika a jego określonością. Ponadto, Delewska-Greń (2002 : 274-8) podczas omawiania zagadnienia określoności pisze, że kategoria ta została zgramatykalizowana (w różnym stopniu) w językach południowosłowiańskich (takich jak bułgarski, macedoński, serbsko-chorwacki czy słoweński), a w pozostałych językach słowiańskich (w tym także polskim), informacja określoności wyrażana jest przy pomocy środków leksykalnych. Nie wspomina natomiast o relacji syntaktycznej orzeczenie-dopełnienie.

O relacji określoności w języku angielskim i systemu aspektualnego w języku greckim wspomina za to Mackridge $(2004,187)$ :

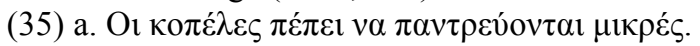

b. Girls should marry young.

c. Dziewczyny powinny wychodzić/wyjść za mąż za młodu.

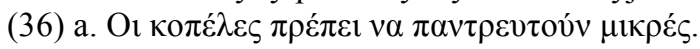

b. The girls should marry young.

c. [te] Dziewczyny powinny wyjść za mąż za młodu.

Odwołuje się do związku aspektu greckiego z użyciem rodzajnika dokonanego w języku angielskim. Moim zdanie, podstawą tego twierdzenia jest nieposiadanie przez język angielski odpowiednio rozwiniętego systemu aspektualnego (podobnie do niemieckiego w przykładzie Nagórko), który został zastąpiony opozycją określoności i nieokreśloności.

\footnotetext{
${ }^{27} \mathrm{Z}$ analizy wyłączone zostały czasowniki nieprzechodnie, które nie przyjmują dopełnienia oraz zdania $\mathrm{w}$ stronie biernej (nawet jeśli patiens nie był domyślny i poprzedzony rodzajnikiem).
} 


\section{Investigationes Linguisticae, vol. XXVI}

Jeżeli spojrzymy na polskie ekwiwalenty greckich i angielskich zdań, to zauważymy, że w przypadku zdania 34 (nieokreślonego w języku angielskim) możliwe jest użycie zarówno formy niedokonanej wychodzić jak i dokonanej wyjść. Różnicę między tymi zdaniami, w mojej opinii, stanowi intencja osoby mówiącej - w pierwszym przypadku ogólność stwierdzenia, w drugim rezultatywność czynności, czyli zmiana statusu cywilnego. W przypadku zdania 35, użycie formy dokonanej można tłumaczyć jednokrotnością czynności, podczas gdy forma ciągła świadczyłaby o jej semelfaktywności.

Idąc dalej, w języku fińskim opozycja aspektualna w zdaniu nie jest wyrażana w ramach systemu werbalnego, lecz syntaktycznie poprzez przypadek przyjmowany przez dopełnienie bliższe ${ }^{28}$. Dopełnienie wyrażone za pomocą przypadka Acc. niesie informację o dokonaności czynności, z kolei wyrażone Part. o niedokonaności. Np.:

(37) a. Hän joit oluen. (Acc.)

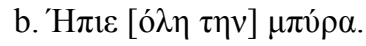

c. Wypił [całe] piwo.

d. Er trank das Bier.

(38) a. Hän joit olutta. (Part.)

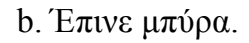

c. Pił piwo.

d. Er trank Bier.

Język grecki, który posiada obecnie oba systemy (aspektualny i określoności) zgramatykalizowane, świadczy o tym, że związek wartości określoności i aspektualności powstał, w językach takich jak angielski czy niemiecki, wtórnie (w obu zdaniach język grecki używa rodzajnika określonego 1. mn. ol) jako rekompensata zubożenia fleksji czasownikowej. Ponadto, wziąwszy pod uwagę, że oba przykładowe języki należą do tej samej rodziny językowej (germańskiej), należy również sprawdzić, czy o podobnej relacji można mówić w przypadku języków z innych rodzin językowych, aby stwierdzić, czy cecha ta jest powszechna, czy też charakterystyczna dla języków germańskich. Jak widać w zdaniach 36 i 37, język fiński nie posiadający ani czasownikowego systemu aspektualnego, ani systemu rodzajników, opozycję dokonaność : niedokonaność wyraża za pomocą form imiennych.

Rozwijając myśl Nagórko (2010, 141), warto w przyszłości podjąć badania na temat relacji aspektu w językach takich jak polski czy grecki a kategorią określoności w językach rodzajnikowych bezprzypadkowych (jak np. język angielski) rodzajnikowych przypadkowych (jak np. niemiecki) bądź bezrodzajnikowych przypadkowych (jak np. fiński) o słabiej rozwiniętej bądź nie posiadającej zgramatykalizowanej kategorii aspektu. Ponadto, choć w niniejszej pracy wspomniany został związek między określonością ilościową obiektu (poprzez użycie liczebników bądź fraz „krotnościowych” (np.: raz, dwa razy, parę razy itp.)), to jednak warto poddać analizie związek policzalności i niepoliczalności rzeczowników z rekcją czasownika, tym bardziej, że dawna składnia genetywu partytywnego obecnie w języku polskim zanika (np. idę kupić chleb : idę kupić chleba, idę kupić mleko : idę kupić mleka, zamierzam codziennie rano kupować mleko : zamierzam codziennie rano kupować mleka).

\subsection{Determinanta aspektowe}

Zarówno w języku polskim jak i greckim istnieją wyrazy oraz frazy, które oprócz informacji semantyczny i gramatycznych, pełnią również funkcję syntaktyczną konotując pewne określone formy innych części zdania. W obu językach można mówić o grupie wyrazów i fraz determinujących aspekt form czasownikowych - o tzw. determinantach aspektowych.

\footnotetext{
${ }^{28}$ Pominięte zostają zdania zanegowane, w których dopełnienie bliższe zawsze wyrażane jest poprzez Part.
} 
Tabela 10. Determinanta aspektowe w języku polskim i greckim ${ }^{29}$

\begin{tabular}{|c|c|}
\hline \multicolumn{2}{|c|}{ DETERMINANTA ASPEKTU NIEDOKONANEGO } \\
\hline polskie & greckie \\
\hline $\begin{array}{l}\text { zaczynać, rozpoczynać, kończyć, kontynuować, } \\
\text { nie przerywać, uczyć (się), mieć zwyczaj, mieć } \\
\text { tendencję, umieć, krótko, długo, codziennie, w } \\
\text { każdy poniedziałek, co tydzień, wieczorami, } \\
\text { itd. }\end{array}$ & 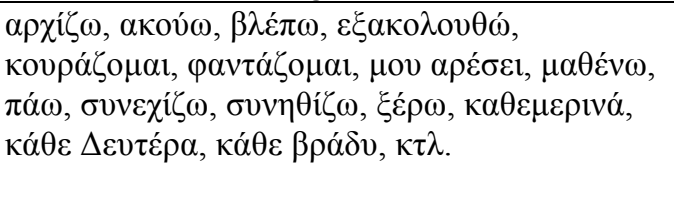 \\
\hline \multicolumn{2}{|c|}{ DETERMINANTA ASPEKTU DOKONANEGO } \\
\hline $\begin{array}{l}\text { prawie, ledwo co, o mały włos, zbliżać się, by, } \\
\text { nigdy nie jest za późno, by, aż, ani razu, itd. }\end{array}$ & 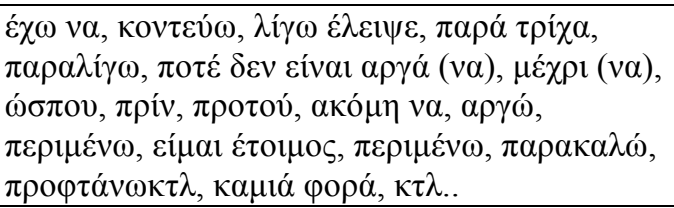 \\
\hline
\end{tabular}

\section{Podsumowanie}

Na podstawie powyższych zestawień można stwierdzić, że język grecki jest bardzo odległy pod względem morfologicznym od języka polskiego i dużo odeń uboższy. Trudno bowiem mówić w nim o faktycznej formie niefinitywnej czasownika, a rzekomy „bezokolicznik” grecki (Triandafillidis, 1997) bliższy jest w swojej konstrukcji do formy bezosobowej (3 os. sg.) dokonanej (tworzonej z tematu aorystu). Funkcja dawnego bezokolicznika w starogreckim została wyparta przez konstrukcję opisową trybu zależnego (Rivero, Ralli, 2001). Ponadto, jej użycie ograniczone jest tylko do konstrukcji czasowych o charakterze perfekcyjnym. Oprócz tego, w przypadku języka polskiego, fleksja tematyczna jest dużo bardziej rozbudowana niż w języku nowogreckim, co można zaprezentować za pomocą tabeli:

Tabela 11. Prefiksy i sufiksy aspektowo-tematotwórcze w języku polskim i greckim

\begin{tabular}{|l|l|}
\hline \multicolumn{1}{|c|}{ Język polski } & \multicolumn{1}{|c|}{ Język grecki } \\
\hline prefiksy: z-, po-, za-, o-, s-, u-, wy-, prze-, & prefiksy: $\varnothing$ \\
ob-, na-, w-, przy-, od-, do-, pod-, roz-, nad- & \\
sufiksy: -owa-, -wa-, -iwa-, -ywa-, -(i)ewa-, & sufiksy: $-\sigma-,(-\xi-,-\psi-),-\theta-,(-\sigma \tau-,-\tau-)$ \\
-ną-
\end{tabular}

Powyższa tabela, która przedstawia afiksalną derywację tematów asektowych, nie obejmuje nieregularnych wymian częśsiowych bądź całkowitych tematu (tematy supletywne) a także alternacji samogłosek tematycznych o charakterze aspektualnym, które są charakterystyczne m. in. dla greckich czasowników urabiających temat dokonany asygmatycznie (m. in. zakończone na spółgłoskę płynną lub nosową) oraz dla licznej grupy czasowników polskich. Najczęstszymi

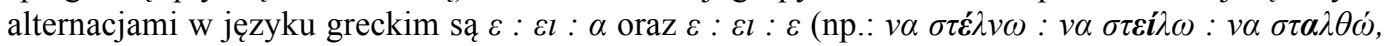

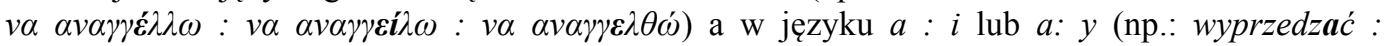
wyprzedzić, zderzać się : zderzyć się)

Pod względem funkcjonalnym aspektualności polskiej i greckiej, można mówić o ich stosunkowo dużym stopniu podobieństwa, gdyż w próbie 112 zdań, tylko $19 \mathrm{z}$ nich różniła się między sobą pod względem aspektu. Do tego, w $6 \mathrm{z}$ nich, polskiej formie bezokolicznika dokonanego odpowiadał ciągły tryb zależny, a w 13 była sytuacja odwrotna. Wynika z tego, że polskiemu aspektowi niedokonanemu odpowiada w języku greckim aspekt dokonany dwa razy częściej niż dokonanemu niedokonany.

W obu językach aspektowi niedokonanemu można przypisać funkcję wyrażania habitualności, iteratywności, inchoatywności, terminatywności, umiejętnościowo-zdolnościową, długotrwałości, i progresywności, a dokonanemu rezultatywności, semelfaktywności, momentalności i teliczności.

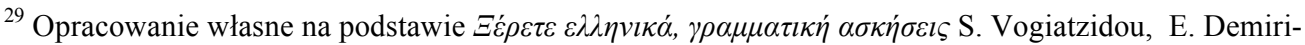
Prodromidou, N.Nikolaidou-Nestora, N. Tryfona-Antonopopoulou, 2000.
} 


\section{Investigationes Linguisticae, vol. XXVI}

Główną różnicę w postrzeganiu rzeczywistości pozajęzykowej przez oba te języki stanowią zamknięte przedziały czasowe, które są w języku polskim markerami przede wszystkim duratywności, trwania czynności (imperfektyw), a w greckim punktualności, zamkniętego okresu o nieistotnej strukturze wewnętrznej (perfektyw). Ponadto, w obu językach aspekt stanowi kategorię niezwykle subiektywną, i której użycie często zależy nie od kontekstu semantycznego czy syntaktycznego, lecz od intencji i punktu widzenia osoby mówiącej. To właśnie z powodu subiektywności kategorii aspektu, warto jest wyodrębnić tzw. aspekt zerowy, który jest używany, gdy zdaniu nie można przypisać konkretnego determinantu aspektowego, a osoba mówiąca pozostaje intencjonalnie neutralna. A zatem, w oparciu o tę tezę, możliwe jest wyodrębnienie zdania aspektowego nienacechowanego (obiektywnego) oraz nacechowanego (intencjonalnego, subiektywnego). Rolę takiego aspektu neutralnego/zerowego miałby pełnić w języku polskim aspekt niedokonany, w greckim dokonany.

Ponieważ niniejsza praca ma charakter strukturalny, a zatem przedmiot badań stanowi relacja między formami gramatycznymi a formalną strukturą zdaniową, nie uwzględniona zostaje teza, o której jest mowa między innymi w Gramatyce konfrontatywnej butgarsko-polskiej (Karolak 2008), że prymarnym wykładnikiem aspektu jest nie gramem lecz semantem. Pomimo to, w przyszłości warto byłoby zbadać czy akcjonalność czasowników ma wpływ na przyjmowane przezeń formy aspektualne, a także czy aspekt zerowy może stanowić imperfektyw bądź perfektyw, w zależności od charakteru (rodzaju czynności) danego czasownika (np. neutralny charakter formy dokonanej czasownika punktowego kichnąć, w stosunku do bardziej wyspecjalizowanej formy iteratywnej kichać). Zakładając, że aspekt zerowy może przyjmować różne wartości w zależności od akcjonalności czasownika, należy zbadać związek aspektu zerowego $\mathrm{z}$ formami prefiksalnymi tworzącymi formy ciągłe wtórnie. Rzuciłoby to nowe światło a także dostarczyłyby nowych materiałów do badań konfrontatywnych nad systemami aspektualnymi języka polskiego i greckiego. 


\section{Bibliografia:}

Comrie, Bernard. 1976. Aspect: an Introduction to the Study of Verbal Aspect and Related Problems. New York: Cambridge University Press.

Cristal, Davide. 2008. A Dictionary of Linguistics and Phonetics. Oxford: Blackwell Publishing.

Dahl, Östen. 1985. Tense and Aspect Systems. Oxford: Basil Blackwell.

Dalewska-Greń, Hanna. 2002. Języki stowiańskie. Warszawa: Wydawnictwo Naukowe PWN.

Fisiak, Jacek. 1990. Further insights into contrastive analysis. Philadelphia: Benjamins.

Grochowski, Maciej, Stanisław Karolak, i Zuzanna Topolińska. 1984. Składnia. Warszawa: Państwowe Wydawnictwo Naukowe.

Grzegorczykowa, Renata. 2004. Wyktady z Polskiej Sktadni. Warszawa: Wydawnictwo Naukowe PWN.

Holton, David, Peter Mackridge, i Eirini Philippaki-Warburton. 1998. Grammatiki tis Ellinikis Glossas. Ateny: Ekdoseis Pataki.

Joseph, Brian D. 1981. The Balkan Infinitive loss - Some methodological problems, [w:] Aronson H. and B. Darden (eds.), Folia Slavica 4 (2-3), Studies in Balkan Linguistics to Honor Eric P. Hamp on His Sixtieth Birthday. Slavica Publishers, str. 300-308.

Jurewicz, Oktawiusz. 1992. Gramatyka historyczna języka greckiego. Warszawa: Wydawnictwo Naukowe PWN.

Karolak, Stanisław. 2008. Gramatyka konfrontatywna bułgarsko-polska. Red. Violetta KoseskaToszewa i Jordan Penčeva. Warszawa: Slawistyczny Ośrodek Wydawniczy.

Klairis, Christos, i Georgios Mpampiniotis. 2005. Grammatiki tis Neas Ellinikis. Ateny: ELLINIKA GRAMMATA.

Klemensiewicz, Zenon. 1968. Zarys Składni Polskiej. Warszawa: Państwowe Wydawnictwo Naukowe.

Kuryłowicz, Jerzy. 1987. Studia językoznawcze, 1. Wybór prac opublikowanych w języku polskim. Warszawa: Państwowe Wydawnictwo Naukowe.

Laskowski, Roman. 1998. Gramatyka Wspótczesnego Języka Polskiego: Morfologia. Red. Renata Grzegorczykowa, Roman Laskowski i Henryk Wróbel. Warszawa: Wydawnictwo Naukowe PWN.

Mackridge, Peter. 2004. I Neoelliniki Glossa: Perigrafiki Analisi tis Neoellinikis Koinis. Ateny: Ekdoseis Pataki - Glossologia 1.

Milewski, Tadeusz. 1972. Językoznawstwo. Warszawa: Państwowe Wydawnictwo Naukowe.

Nagórko, Alicja. 2000. Zarys gramatyki polskiej (ze słownictwem). Warszawa: Wydawnictwo Naukowe PWN.

Nagórko, Alicja. 2010. Podręczna gramatyka języka polskiego. Warszawa: Wydawnictwo Naukowe PWN.

Rivero, Maria. L., i Angela Ralli. 2001. Comparative Syntax of Balcan language. Nowy Jork: Oxford University Press.

Saloni, Zygmunt, i Marek Świdziński. 2007. Składnia Współczesnego Języka Polskiego. Warszawa. Wydawnictwo Naukowe PWN.

Triandafillidis, Manolis A. 1997. Mała gramatyka nowogrecka. Tłum. Irena SzelągiewiczEllenikos, Anna Maciejewska, Wanda Gawłowska, Saloniki: Uniwersytet im. Arystotelesa w Salonikach. Instytut Studiów Nowogreckich. Fundacja Manolisa Triandafillidisa.

Vogiatzidou, Smaro, Eleni Demiri-Prodromidou, i Neli Nikolaidou-Nestora. 2000. Kserete Ellinika, grammatiki askiseis. Saloniki: Ekdoseis Epistimoniakon Vivlion kai Periodikon. 